\title{
Dualisme Konteks Proper sebagai Instrumen Penaatan Sukarela dan Command and Control ${ }^{1}$
}

\author{
Faisol Rahman ${ }^{2}$
}

\begin{abstract}
Abstrak
Kehadiran penaatan sukarela (voluntary approach) di negara berkembang telah menjadi alternatif untuk mendorong penaatan hukum. Penaatan sukarela dapat menjadi pelengkap instrumen atur dan awasi (command and control), untuk mengatasi keterbatasan sumber daya dan minimnya kemauan politik pemerintah. Proper yang pada masa awalnya merupakan salah satu instrumen penaatan sukarela yang dapat mendorong ketaatan hukum pesertanya. Namun belakangan, Proper dikritik karena tidak memberikan sanksi terhadap pesertanya yang berperingkat tidak taat. Pada titik singgung ini, menjadi bias pemaknaan Proper antara konteks penaatan sukarela dan command and control.

Artikel ini mengkaji secara normatif adanya dilema penerapan sanksi dalam Proper oleh KLHK selaku penyelenggara Proper. Dimana non-peserta Proper, cenderung mendapatkan keleluasaan akibat ketiadaan sistem pengawasan dan penegakan hukum. Sedangkan peserta Proper, yang secara sukarela telah bekerja sama untuk mempermudah pengawasan pemerintah, terancam sanksi apabila ditemukan pelanggaran. Sehingga apabila sanksi diterapkan terhadap peserta, dapat memberikan tekanan terhadap kesukarelaan peserta untuk melanjutkan kerja samanya dalam Proper.
\end{abstract}

Kata Kunci: penaatan sukarela, penegakan hukum lingkungan, proper

\section{Abstract}

The presence of voluntary approach in developing countries has become an alternative to encourage legal compliance. Voluntary compliance can be a complement to the command and control, to overcome the limited resources of powerlessness and the lack of political will of the government. Proper which in the beginning was one of the instruments of voluntary compliance has been proven to be able to encourage the legal observance of its participants. But lately, Proper has been criticized for not giving sanctions to its participants who are ranked disobedient. At this point of contact, there is a bias in the meaning of Proper between the context of voluntary compliance and command and control.

This article examines normatively the existence of the dilemma of applying sanctions in Proper by KLHK as the organizer of Proper. Where non-participants are Proper, tend to get discretion due to the absence of a system of supervision and law enforcement. While Proper participants,

${ }^{1}$ Hasil penelitian bersama Bagian Penelitian Departemen Hukum Lingkungan Universitas Gadjah Mada tahun 2019.

2 Alumni Magister Ilmu Hukum, Fakultas Hukum Universitas Gadjah Mada. 
who have voluntarily worked together to facilitate oversight by the government, are threatened with sanctions if violations are found. So that if sanctions are applied to participants, they can put pressure on the volunteerism of participants to continue working together in Proper.

Keywords: voluntary approach, environmental law enforcement, proper

\section{Pendahuluan}

Proper merupakan program pemerintah pertama yang menunjukkan keberhasilan dalam upaya mengatur dan mengatasi pencemaran dari industri. ${ }^{3}$ Saat ini, Proper masih menjadi program terbesar dari Kementerian Lingkungan Hidup dan kehutanan (KLHK) yang secara khusus mengawasi ketaatan hukum usaha dan/atau kegiatan dalam upaya pengelolaan lingkungan.

Sayangnya, masih banyak perusahaan yang meraih peringkat tidak taat, yaitu merah dan hitam. KLHK tidak pernah mempublikasikan adanya penjatuhan sanksi terhadap perusahaan berperingkat merah, yang disinyalir telah melanggar ketentuan peraturan perundangan. Akibatnya, KLHK selaku penyelenggara mendapatkan kritik karena tidak menja- tuhkan sanksi hukum kepada para pesertanya. ${ }^{4}$

Adanya dualisme konteks, Proper sebagai instrumen Command and Control dan penaatan sukarela, ${ }^{5}$ telah semakin mengakibatkan ketidakjelasan arah dalam menentukan mekanisme penjatuhan sanksi yang tepat terhadap peserta Proper. Karenanya, diperlukan kajian terhadap konsep dan penerapan sanksi dalam Proper, yang diharapkan dapat menjadi masukan untuk meningkatkan kinerja Proper.

\section{Penaatan Sukarela Dalam Hukum Lingkungan}

\section{A. Manfaat Penaatan Sukarela}

Kebijakan hukum lingkungan terdiri atas empat kategori, yaitu instrumen command and control (CAC), instrumen ekonomi, strategi berbasis informasi (in-

3 Tom Tietenberg, "Disclosure Strategies for Pollution Control," Environmental and Resource Economics, Vol. 11, 3-4 (1998), hlm. 587-602; Jorge Garcia Lopez, The Institutional History Of Indonesia's Environmental Rating And Public Disclosure Program - Proper , 2011, sumber : http:/ / erblegacy.snre. umich.edu/News-and-Events/news-events-docs/11-12/eco-labels2011/JorgeGarciaLopez.pdf, diakses tanggal 14 Juli 2018

${ }^{4}$ Michikazu Kojima, «Rating Programme Revisited: In the Case of Indonesia», dalam Tadayoshi Terao, Kenji Otsuka, Development of Environmental Policy in Japan and Asian Countries, (Palgrave Macmillan, 2007), hlm. 171-172.

${ }^{5}$ Menurut Wibisana dan Bram, maka Proper sesungguhnya tidak bisa sepenuhnya dianggap sebagai instrumen penaatan sukarela. Proper merupakan campuran antara instrumen penaatan sukarela dan CAC. Lihat dalam Andri G. Wibisana, Penaatan Hukum Lingkungan: Command and Control, Instrumen Ekonomi, dan Penaatan Sukarela (Bahan Ajar Fakultas Hukum UI, 2016), hlm.16-17 
formation disclosure) dan penaatan sukarela (voluntary approach). ${ }^{6}$ Penaatan sukarela diartikan sebagai suatu keadaan dimana perusahaan secara sukarela, atas inisiatifnya sendiri membuat komitmen dan meningkatkan kinerja pengelolaan lingkungannya, meskipun tidak diwajibkan oleh peraturan perundangan atau tanpa paksaan pemerintah. ${ }^{7}$ Dalam implementasinya mencakup berbagai bentuk pengaturan yang berbeda-beda di berbagai negara, dimana mencakup keragaman jenis, terminologi, dan pihak-pihak yang terlibat. ${ }^{8}$ Bahkan dalam beberapa implementasinya bertujuan untuk melampaui kinerja pengelolaan lingkungan yang ditetapkan dalam ketentuan peraturan perundangan. ${ }^{9}$ Be- berapa bentuk program sukarela yang dikenal, misalnya ISO dan Responsible Care di seluruh dunia, EMAS di Eropa, Covenant di Belanda, "33/50" di Amerika serta Proper Lingkungan dan Ekolabel (Swadeklarasi) di Indonesia. ${ }^{10}$

Penaatan sukarela dapat menjadi pelengkap CAC yang selama ini menjadi tulang punggung penegakan hukum lingkungan. Perbedaan implementasi antara $C A C$, penaatan sukarela, dan instrumen ekonomi tergambar dari kecenderungan pemerintah untuk mewujudkan ketaatan perusahaan dalam pengelolaan lingkungan, yaitu apakah menggunakan tongkat (stick), wortel (carrot) ataukah keduanya. ${ }^{11}$ Sebagai gambarannya, melalui CAC upaya pengendalian pence-

\footnotetext{
${ }^{6}$ Rory Sullivan, Rethinking Voluntary Approaches in Environmental Policy, (London: Edward Elgar, 2005), hlm. 33.

${ }^{7}$ Baca Carlo, Carraro. Francois, Leveque, "The rationale and potential of voluntary approaches", dalam Carlo Carraro, Francois Leveque (eds), Voluntary Approaches in Environmental Policy (Netherlands: Kluwer Academic Publishers, Dordrecht, 1999), hlm. 2-3.

${ }^{8}$ Penaatan sukarela telah diciptakan oleh mereka yang merancang dan mengimplementasikannya, yaitu para pembuat kebijakan, asosiasi bisnis, perusahaan, atau lembaga non-pemerintah. Sehingga belum ada terminologi baku yang dapat menggambarkan secara keseluruhan bentuk-bentuk penaatan sukarela yang telah diterapkan di seluruh dunia. Bahkan, pada suatu negara yang berbeda, dapat menggunakan istilah yang sama untuk menggambarkan hal-hal yang sangat berbeda dalam penerapannya. Karenanya terdapat berbagai istilah yang digunakan untuk menyebut istilah penaatan sukarela, antara lain pendekatan sukarela, inisiatif sukarela, program sukarela, kode sukarela, kesepakatan sukarela, instrumen sukarela, pengaturan mandiri, pengaturan diri sendiri, perjanjian, perjanjian sukarela, perjanjian pengendalian pencemaran, dan perjanjian lingkungan, atau yang oleh Otto Soemarwoto diistilahkan dengan Atur Diri Sendiri. Baca dalam OECD, Voluntary Approaches for Environmental Policy: An Assessment, (Paris: OECD, 1999), hlm. 8-9 dan Otto Soemarwoto, Atur Diri Sendiri, (Yogyakarta: Gadjah Mada University Press, 2004), hlm. 108.

${ }^{9}$ OECD, Voluntary Approaches for Environmental Policy: An Assessment, (Paris: OECD, 1999) hlm. 8; Rory Sullivan, Op. Cit., hlm. 4; James A. Cunningham, Free riders and environmental voluntary approaches, Progress in Industrial Ecology - An International Journal, Vol. 3, No. 5, (2006). OECD memberikan definisi penaatan sukarela, yaitu "whereby firms make commitments to improve their environmental performance beyond what the law demands"

${ }^{10}$ Indonesia, (a) Peraturan Menteri Lingkungan Hidup tentang Pencantuman Logo Ekolabel, Permen LH No. 2 2014, BN Nomor 167 Tahun 2014, ps. 1

${ }^{11}$ Daniel J. Fiorino, The New Environmental Regulation, (England: The MIT Press, 2006), hlm. 144-146.
} 
maran dilaksanakan dengan membuat peraturan perundangan yang memaksa perusahaan mengendalikan pencemaran. Sementara, penaatan sukarela memberikan bantuan insentif/disinsentif, bukan sekadar kewajiban hukum. ${ }^{12}$

Lebih lanjut menurut Oates dan Baumol sebagaimana dikutip Wibisana, bahwa berbeda dari instrumen ekonomi yang didasarkan atas adanya insentif ekonomi bagi kinerja lingkungan, penaatan sukarela didasarkan atas ketiadaan penegakan hukum, sehingga langkah penaatan hukum merupakan keputusan sukarela suatu perusahaan. ${ }^{13}$

Dalam praktiknya, istilah "sukarela" mungkin tidak benar-benar akurat karena kesukarelaan sering diterapkan sebagai tanggapan atas tekanan konsumen, masyarakat, sesama perusahaan (persaingan), atau adanya ancaman sanksi, pungutan, dan peraturan baru. ${ }^{14}$ Sebaliknya, bentuk-bentuk peraturan pemerintah yang paling ketat, akan berlaku beberapa elemen sukarela. ${ }^{15}$

Menurut Fiorino, penaatan sukarela adalah cara mengubah hubungan "permusuhan" antara pemerintah, industri, dan pencinta lingkungan. Debat hukum dan peraturan diganti diskusi dan kerja sama pengendalian pencemaran dengan para pemangku kepentingan, efisiensi sumber daya, dan langkah-langkah untuk meningkatkan kinerja lingkungan. ${ }^{16}$ Hubungan kooperatif diharapkan akan meningkatkan kinerja penegakan hukum yang lebih baik daripada hubungan permusuhan. ${ }^{17}$

Penaatan sukarela memberikan manfaatnya melalui fleksibilitas kepada perusahaan sehingga dapat menekan biaya pengelolaan lingkungan. Pemberian fleksibilitas oleh Pemerintah kepada perusahaan peserta dilakukan ketika pelanggaran yang tidak disengaja ditemukan (dapat memaafkan pelanggaran hukum yang bersifat teknis atau ringan) dan bekerja sama dengan perusahaan untuk dapat memecahkan akar penyebab dari ketidaktaatan. ${ }^{18}$

Beberapa ahli menyarankan bahwa diperlukan program penegakan hukum yang kuat; tetapi penjatuhan sanksi denda, hukuman, dan pidana harus menjadi pilihan terakhir, yang diterapkan setelah aparatur pemerintah mencoba un-

${ }^{12}$ Allen Blackman, Et. Al., Voluntary Environmental Agreements in Developing Countries- The Colombian Experience, Resources For Future (RFF), DP/12-06, Februari 2012

${ }^{13}$ Andri G. Wibisana, Op.Cit., hlm.16-17.

${ }^{14}$ OECD, Op. Cit., hlm. 9.

${ }^{15}$ Rory Sullivan, Op.Cit. hlm. 38.

${ }^{16}$ Daniel J. Fiorino, Op. Cit., hlm. 136.

${ }^{17}$ John T. Scholz, «Cooperative regulatory enforcement and the politics of administrative effectiveness», American Political Science Review, Vol. 85 No. 1, (1991).

${ }^{18}$ Matthew Potoski, Aseem Prakash, Voluntary Programs, Compliance and The Regulation Dilemma, dalam David Levi-Faur, Handbook on the Politics of Regulation, (USA:Edward Elgar, 2011), hlm. 85. 
tuk mendorong ketaatan atau dimana dampak lingkungan telah terjadi akibat ketidaktaatan. ${ }^{19}$ Sebaliknya, perusahaan diharapkan bekerja sama dengan itikad baik untuk melaksanakan penaatan hukum dan secara sukarela mengungkapkan pelanggaran yang ditemukannya.

Lebih lanjut, bahwa Perusahaan memiliki informasi, pengetahuan, pengalaman dan pemahaman yang lebih baik tentang ruang lingkup kegiatan usaha atau proses produksinya. Kapasitas tersebut sayangnya belum didayagunakan untuk meningkatkan inovasi dalam pengelolaan lingkungan. ${ }^{20}$ Terkait informasi asimetris ${ }^{21}$, maka kompleksitas dan tingkat permasalahan lingkungan menjadikan pelibatan proaktif perusahaan menjadi suatu keniscayaan. ${ }^{22}$ Inilah pembenaran penaatan sukarela yang mendorong langkah pengaturan man- diri perusahaan untuk mengelola risiko lingkungannya. ${ }^{23}$

Penaatan sukarela juga bertujuan untuk memperbaiki ketidaktaatan hukum karena ketidaksengajaan dan/atau ketidaktahuan, misalnya ISO dan Emas yang mensyaratkan suatu target kinerja yang harus dilaksanakan kepada suatu perusahaan. ${ }^{24}$ Selain itu, Penaatan sukarela dapat menyediakan forum penyebaran informasi tentang teknik pengendalian pencemaran, pembelajaran secara kolektif, pengembangan kompetensi manajemen dan bentuk interaksi yang lebih baik yang mengarah pada peningkatan hubungan kepercayaan antara anggotanya. ${ }^{25}$

Kebijakan lingkungan selalu berupaya menemukan pilihan instrumen kebijakan yang dapat meningkatkan kinerja lingkungan dengan biaya serendah

${ }^{19} \mathrm{Al}$ Iannuzzi, Jr., Industry Self-Regulation and Voluntary Environmental Compliance, (United States: CRC Press, 2002), hlm. 6-8.

${ }^{20}$ David E. Adelman, Climate Change, Federalism, and Promoting Technological Change. dalam Alyson C., Flournoy. David M., Driesen (editor). Beyond Environmental Law, Policy Proposals For A Better Environmental Future, (Cambridge University Press. 2010), hlm. 215.

${ }^{21}$ Ketika dua atau lebih individu saling berinteraksi, antara pemerintah dan perusahaan misalnya, informasi asimetris terjadi saat satu individu memiliki pengetahuan yang lebih baik daripada individu lainnya yang tidak memiliki informasi. Sedangkan Informasi simetris ketika semua pihak mengetahui semua informasi relevan yang dimiliki oleh orang lain yang terlibat dalam pertukaran. Namun, sebagian besar kegiatan ekonomi melibatkan beberapa kegagalan untuk memenuhi kondisi ini. Robert W., Kolb. Encyclopedia of business ethics and society, (Sage Publication, 2008), hlm. 123.

${ }^{22}$ Theo de Bruijn dan Vicki Norberg-Bohm, Innovations in the Environmental Policy System: Voluntary, Collaborative and Information-Based Policies in the United States and the Netherlands dalam Matthias Weber dan Jens Hemmelskamp, Towards Environmental Innovation Systems, (Springer, 2005) hlm. 269.

${ }^{23}$ Shanti Gamper-Rabindran, Stephen R. Finger, "Does industry self-regulation reduce pollution? Responsible Care in the chemical industry", Journal of Regulatory Economics, 43:1-30, (2013).

${ }^{24}$ Aseem Prakash, Matthew Potoski, "Voluntary Environmental Programs: A Comparative Perspective", Journal of Policy Analysis and Management, Vol. 31, No. 1 (2012), pp. 123-138.

${ }^{25}$ Rory Sullivan, Op.Cit., hlm. 26.

${ }^{26}$ Charles J. Higley and François Lévêque, Environmental Voluntary Approaches: Research Insights for Policy-Makers, (CERNA, Centre d'économie industrielle Ecole Nationale Supérieure des Mines de Paris, 2001). 
mungkin. ${ }^{26}$ Goodwill pemerintah dapat mengarah pada hubungan kolaboratif di mana pemerintah dapat mendorong perbaikan lingkungan yang lebih optimal melalui hubungan berbasis kepercayaan atau kerja sama yang mendorong pembelajaran bersama. ${ }^{27}$ Melalui penaatan sukarela pemerintah mendorong perusahaan dengan memberikan imbalan kepada perusahaan yang telah mengeluarkan "biaya" dengan mengadopsi penaatan sukarela. Misalnya melalui peningkatan reputasi, hubungan kerja sama dan itikad baik para pemangku kepentingan eksternal hingga bantuan teknis lainnya. ${ }^{28}$

\section{B. Penaatan Sukarela di Negara Berkembang}

Blackman et.al., mengungkapkan, bahwa pemerintah di negara maju umumnya menerapkan penaatan sukarela untuk mendorong ketaatan yang melampaui hukum (beyond compliance). Sedangkan di negara berkembang, digunakan untuk membendung ketidakta- atan yang merajalela akibat ketidakberdayaan penegakan hukum, ketidaklengkapan peraturan, lemahnya kelembagaan lingkungan, dan terbatasnya kemauan politik pemerintah. ${ }^{29}$

Sebagai contohnya, program Industri Bersih di Meksiko (Mexico's Clean Industry Program/ MCIP), ${ }^{30}$ yang diselenggarakan oleh The Federal Environmental Attorney General's Office/Profepa). Dimana melalui MCIP, Profepa telah berhasil mendorong ketaatan hukum perusahaan. ${ }^{31}$ MCIP juga telah mengefisiensikan sumber daya manusia dan keuangan Profepa yang terbatas, dengan mengalihkan biaya pemantauan lingkungan kepada perusahaan, melalui pelaksanaan audit lingkungan oleh pihak ketiga yang tersertifikasi. Sebagai timbal baliknya, Profepa memberikan sertifikasi yang membebaskan perusahaan dari pengawasan Profepa selama dua tahun dan dapat menjadi publikasi yang positif bagi perusahaan. ${ }^{32}$

${ }^{27}$ Nicole Darnall, Matthew Potoski, "Sponsorship matters: Assessing business participation in government and industry sponsored voluntary environmental programs," Journal of Public Administration Research and Theory, Vol. 20 (2010).

${ }^{28}$ Cary Coglianese dan Jennifer Nash, Motivating Without Mandates: The Role of Voluntary Programs in Environmental Governance, (2016). Faculty Scholarship. Paper 1647; Nicole Darnall, Matthew Potoski, Op.Cit.

${ }^{29}$ Allen Blackman Et.Al., Op. Cit; Allen Blackman, "Can Voluntary Environmental Regulation Work in Developing Countries? Lessons from Case Studies," The Policy Studies Journal, Vol. 36, No. 1 (2008); Allen Blackman, Voluntary Environmental Regulation in Developing Countries (Fad or Fix?), Resources for the Future (RFF) DP 07-10, 2007. Blackman Et. AL., melakukan penelitian terhadap implementasi penaatan sukarela di negara Meksiko, India, dan Indonesia (Proper Prokasih) serta didasarkan juga atas literatur penelitian yang dilakukan di negara Cina dan Kostarika. Baca lebih lanjut dalam Blackman Et. AL., Op.Cit., 2008.

30 Program ini dikenal juga dengan Program Audit Lingkungan Sukarela (the National Environmental Auditing Program), Ibid.

${ }^{31}$ Ibid.

${ }^{32}$ Ibid. 
Pemerintah Meksiko juga menerapkan Perjanjian Sukarela (Negotiated Agreements) untuk mengendalikan polusi yang dihasilkan oleh ratusan industri penyamakan kulit di León, Guanajuato, Meksiko. Namun, perjanjian yang telah dilaksanakan sebanyak 4 gelombang di tahun 1987, 1991, 1995 dan 1997, dapat dikatakan tidak berhasil. ${ }^{33}$ Menurut Blackman et.al., kegagalan tersebut diakibatkan oleh lemahnya tekanan penegakan hukum, tekanan non-penegakan hukum, penangkapan regulasi (regulatory capture) oleh perusahaan dan tidak adanya peningkatan tekanan non regulasi melalui publikasi ketidakpatuhan oleh perusahaan. ${ }^{34}$

Lebih lanjut Blackman meneliti pertentangan terhadap manfaat penaatan sukarela di negara berkembang. Penaatan sukarela dikritik karena lemahnya tekanan regulasi pemerintah dan non regulasi oleh para pemangku kepentingan, potensi regulatory capture, serta banyaknya perusahaan skala kecil/informal di negara berkembang. Sedangkan pendukungnya berpendapat, bahwa penaatan sukarela dapat mengesampingkan kendala terkait regulasi. Karena sesuai defi- nisinya, penaatan sukarela tidak bergantung pada regulasi untuk memotivasi kinerja lingkungan perusahaan.

Motivasi perusahaan bergantung terhadap dua jenis insentif. ${ }^{35}$ Pertama, dengan meningkatkan reputasi kinerja lingkungan suatu perusahaan, penaatan sukarela dapat meningkatkan tekanan positif dan negatif kepada perusahaan pencemar, oleh para pemangku kepentingan. Misalnya, investor dapat mengaitkan buruknya kinerja lingkungan dengan kinerja keuangannya, konsumen hijau dapat mengekspresikan kepada perusahaan hijau dengan membeli produk mereka di pasar $^{36}$ dan kemudahan izin sosial (social license). ${ }^{37}$ Meskipun diakui, bahwa kekuatan para pemangku kepentingan di negara berkembang cenderung lebih lemah dibandingkan di negara maju. ${ }^{38}$

Kedua, inisiatif sukarela seringkali memberikan subsidi untuk pengendalian pencemaran. Subsidi umumnya berupa penyediaan informasi, melalui penyelenggaraan seminar, brosur atau sarana interaksi dan komunikasi yang dapat memberikan pengetahuan sekaligus bantuan teknis dalam upaya pengendali-

${ }^{3}$ Ibid.

${ }^{34}$ Ibid.

${ }^{35}$ Baca lebih lanjut dalam Allen Blackman, (2007), Op. Cit.

${ }^{36}$ Aseem Prakash, Matthew Potoski, 2012, Op.Cit.

${ }^{37}$ Neil Gunningham, Robert A. Kagan, Dorothy Thornton, Social License and Environment Protection: Why Businesses Go Beyond Compliance, 29 Law \& Soc. Inquiry 307, 2004.

${ }^{38}$ Allen Blackman, 2008, Op. Cit. 
an pencemaran. Selain itu, dapat berupa uang, hibah dan pinjaman untuk peralatan pengendalian polusi.

\section{Penaatan Hukum}

\section{A. Penaatan Hukum Lingkungan dalam Konteks Command and Control}

Pendekatan utama yang selama ini didayagunakan untuk mencapai penaatan lingkungan adalah Atur dan Awasi $(\mathrm{ADA})^{39}$ atau Command And Control (CAC) atau direct regulation. ${ }^{40}$ Instrumen CAC didasarkan atas keyakinan, bahwa tanpa adanya paksaan dari pemerintah, maka perusahaan tidak akan secara sukarela untuk berupaya memberikan manfaat sosial (eksternalitas positif) yang non-excludeable (dapat dinikmati semua orang) $\cdot{ }^{41}$ Misalnya perusahaan tidak akan secara sukarela untuk berupaya meminimalisasi dampak negatif dan sebaliknya memperbesar dampak positif terhadap lingkungan yang ditimbulkan dari usaha dan/atau kegiatannya. Di- mana pengaturan hukum atau peraturan perundangan dianggap sebagai faktor eksternal paling penting dalam mempengaruhi dan mendorong perusahaan untuk berperilaku ramah lingkungan. ${ }^{42}$

Pendekatan CAC dirancang untuk melarang atau membatasi kegiatan yang berbahaya bagi lingkungan berupa pencemaran dan/atau perusakan lingkungan. Pengaturan ini menggunakan mekanisme perintah-dan-kontrol yang mengidentifikasi target lingkungan, seperti baku mutu emisi lingkungan yang diperbolehkan untuk dilepaskan ke air atau udara (the command), dengan sanksi atau hukuman yang akan dijatuhkan apabila target tidak terpenuhi (the control). ${ }^{43}$ Konsep dasarnya adalah tugas pemerintah untuk mengumpulkan informasi yang dibutuhkan untuk mengambil langkah pengendalian pencemaran dan kemudian memerintahkan perusahaan pencemar melaksanakan suatu tindakan tertentu. ${ }^{44}$

\footnotetext{
${ }^{39}$ Otto Soemarwoto, Op.Cit., hlm. 5

${ }^{40}$ Baca dalam Andri G. Wibisana, "Instrumen Ekonomi, Command and Control, dan Instrumen Lainnya: Kawan atau Lawan? Suatu Tinjauan Berdasarkan Smart Regulation”, Bina Hukum Lingkungan, VoL. 4, No. 1, (Oktober 2019).

Istilah command and control diketahu berasal dari istilah militer dan sistem pemrosesan informasi, yang awalnya dikenal untuk dipergunakan dam mendeskripsikan suatu kebijakan hukum (regulation). Baca dalam Daniel H. Cole, “Explaining the Persistence of 'Command-and-Control' in US Environmental Law", Legal Studies Research Paper Series, No. 380 (2017).

${ }^{41}$ Nicole Darnall, Matthew Potoski, Op. Cit.

${ }^{42}$ Ian Worthington, Op.Cit., hlm. 71

${ }^{43}$ Neil Gunningham, Darren Sinclair, "Regulatory Pluralism: Designing Policy Mixes for Environmental Protection", Law and Policy, Vol. 21, No. 1, (1999).

${ }^{44}$ Lihat dalam Michael Faure, et.al., "Economic Instruments: Suited to Developing Countries?", dalam Michael Faure dan Nicole Niessen (eds.), Environmental Law in Development: Lessons From The Indonesian Experience, (Cheltenham, UK: Edward Elgar, 2006), hlm. 220-221
} 
Dalam praktiknya, pemerintah secara sepihak akan mendikte perusahaan atau calon pencemar, untuk melaksanakan suatu tindakan atau perilaku tertentu, dalam bentuk kewajiban hukum, yang diiringi sanksi hukum yang dapat dipaksakan, yang telah diatur dalam hukum atau peraturan perundangan. Sehingga, karakteristik yang khas dari instrumen CAC adalah, adanya perintah (command) yang disertai mekanisme penegakan hukum dan sanksi (control) oleh pemerintah kepada perusahaan yang tidak menjalankan berbagai bentuk kewajiban hukumnya.

Anthony Ogus sebagaimana dikutip oleh Faure et.al., telah mengategorikan CAC sesuai dengan tingkat intervensi pemerintah, mulai dari campur tangan yang paling rendah, seperti pengungkapan informasi dan instrumen ekonomi. Campur tangan yang sedang, berbentuk standar atau baku mutu lingkungan. ${ }^{45}$ Terakhir, campur tangan paling intervensionis, yakni melalui sistem perizinan. ${ }^{46}$

Berdasarkan kriteria tersebut, maka dalam memilih instrumen CAC yang akan diterapkan, sudah sepantasnya apabila Pemerintah mempertimbangkan dengan kondisi sumber daya atau kemampuan yang dimilikinya. Dalam aspek perizinan misalnya, apabila pemerintah tidak mampu untuk mengendalikan perizinan yang dikeluarkannya, maka patutlah dipertimbangkan instrumen lainnya yang lebih mudah untuk diawasi (control), melalui pengungkapan informasi misalnya.

\section{B. Implementasi Command and Control Berdasarkan UUPPLH}

UUPPLH adalah landasan hukum bagi pemerintah dalam mengimplementasikan instrumen CAC di Indonesia. Melalui UUPPLH, Pemerintah diberikan wewenang untuk menyusun, merencanakan dan menetapkan suatu perintah dan larangan, seperti standar baku mutu lingkungan yang dalam implementasinya umumnya dikombinasikan dengan sistem perizinan, yang mencakup izin lingkungan dan dokumen lingkungan hidup. ${ }^{47}$ Menurut Pasal 20 dan 21 UUPPLH, baku mutu lingkungan hidup mencakup baku mutu pencemaran lingkungan, misalnya baku mutu air, air

${ }^{45}$ Misalnya standar desain (design or specification standards) yang mewajibkan suatu teknologi tertentu untuk proses atau masalah lingkungan tertentu, standar kinerja (performance standards) dengan menentukan kinerja atau tindakan yang harus dicapai dan standar proses (process standards) yang menentukan prosedur atau langkah-langkah yang harus ditaati untuk mencapai target lingkungan yang telah ditetapkan. Lihat dalam Neil Gunningham, Darren Sinclair, 1999, Op.Cit.

${ }^{46}$ Ibid.

${ }^{47}$ Dokumen Lingkungan Hidup (DLH) mencakup dokumen Analisis Mengenai Dampak Lingkungan (Amdal), Upaya Pengelolaan dan Pemantauan Lingkungan (UKL-UPL) dan Surat Peryataan Pengelolaan Lingkungan (SPPL). Indonesia, (b) Peraturan Menteri Lingkungan Hidup tentang Penyusunan Dokumen Lingkungan Hidup (DLH), Permen LH No. 16 2012, BN Nomor 990 Tahun 2012, ps. 2 
limbah, air laut, emisi dan udara ambien serta baku mutu kerusakan lingkungan, misalnya baku mutu kerusakan tanah, mangrove, padang lamun dan gambut.

Selain itu UUPPLH juga menjadi dasar bagi aparatur pemerintah untuk menjalankan fungsi kontrol, melalui penegakan hukum lingkungan. Kewenangan tersebut mencakup pelaksanaan pemantauan, pengawasan dan penjatuhan sanksi yang telah ditetapkan, apabila terjadi ketidaktaatan terhadap perintah atau larangan yang telah ditetapkan.

Dalam pelaksanaan, idealnya diwujudkan menjadi suatu siklus yang saling terkait diantara berbagai unsur perintah dan kontrol. ${ }^{48}$ Dimana dalam penyusunan, perencanaan, pengaturan/ penetapan, pemantauan, pengawasan dan penjatuhan sanksi akan berjalan sesuai dengan siklus yang saling terkait. Sehingga apabila terdapat kelemahan pada satu unsur, misalnya rendahnya tingkat penjatuhan sanksi oleh pemerintah, dapat menyebabkan seluruh unsur dalam instrumen CAC menjadi tidak optimal.

\section{Proper}

\section{A. Perkembangan dan Implemen- tasi Proper di Indonesia}

Proper ditetapkan melalui Keputusan Menteri Negara Lingkungan Hidup (Kepmenlh) No: KEP/-35A/MENLH/7/1995 tentang Program Penilaian Kinerja Perusahaan/ Kegiatan Usaha Dalam Pengendalian Pencemaran Dalam Lingkup Kegiatan Prokasih (Proper Prokasih). Menurut Afsah et.,al., selama periode Proper tahun 1995-1996, Proper berhasil mendorong perusahaan berkinerja tidak taat menuju ketaatan, sekaligus memotivasi perusahaan untuk mengejar peringkat yang melebihi persyaratan hukum dan berinvestasi dalam pencegahan polusi. ${ }^{49}$

Keberhasilan Proper Prokasih telah dikenal secara internasional. ${ }^{50}$ Program yang mendapat bantuan dari CIDA, AUS-AID dan Bank Dunia pada tahun 1998 dihentikan akibat krisis ekonomi dan politik. ${ }^{51}$ Melalui Kepmenlh No: 127/MENLH/2002 tentang Program

${ }^{48}$ Lihat siklus CAC dalam Andrew. Farmer, Handbook of Environmental Protection and Enforcement, Principle and Practice,. (London: Routledge, 2007), hlm. 8-9.

${ }^{49}$ Shakeb Afsah et.al., "Regulation In The Information Age, Indonesian Public Information Program for Environmental Management," Conference Proceedings, 1997; Tom Tietenberg, op. cit.

${ }^{50}$ Michikazu Kojima, Op. Cit., hlm. 172; Indonesia, Kementerian Lingkungan Hidup, Sekilas Proper, Dulu, Sekarang dan Masa Mendatang, (Deputi Bidang Dampak Pengendalian Sumber Institusi, 2005), hlm. 3.

Proper Prokasih menjadi contoh program untuk meningkatkan penaatan perusahaan oleh berbagai negara, seperti Filipina (Ecowatch), Mexico (Public Environmental Performance Index-PEPI), China (Greenwatch), Bangladesh, India, Thailand, Papua New Guinea, Venezuela, Columbia dan Ghana (Akoben). Proper juga mendapat penghargaan Zero Emission Award dari UN University Tokyo dan Landmark Initiative oleh World Bank.

${ }^{51}$ Ibid., hlm.4 
Penilaian Peringkat Kinerja Perusahaan Dalam Pengelolaan Lingkungan Hidup diluncurkan lah Proper.

Saat ini landasan hukum Proper adalah Permenlh Nomor 3 Tahun 2014 tentang Proper (Permen Proper). Ruang lingkup Proper semakin luas mencakup, aspek ketaatan sebagaimana diatur dalam Pasal 5 Permen Proper, yang secara substansial merupakan wujud penerapan CAC sebagaimana telah diatur dalam peraturan perundangan yang berlaku (regulatory based $)^{52}$. Selain itu juga mencakup delapan (8) aspek melebihi ketaatan (beyond compliance) yang mencakup evaluasi terhadap kinerja usaha dan/atau kegiatan yang melebihi ketaatan dari yang diprasyaratkan oleh peraturan perundang-undangan atau melebihi ruang lingkup kriteria yang tercakup dalam aspek ketaatan Proper, misalnya kriteria sistem manajemen lingkungan dan efisiensi energi. ${ }^{53}$

Pelaksanaan Proper diawali dengan pemilihan perusahaan peserta. Tidak semua perusahaan dapat menjadi peserta
Proper. Menurut Pasal 8 dan Pasal 3 Permen Proper, maka penetapan perusahaan menjadi peserta Proper didasarkan atas kriteria, yaitu pelaksanaan Proper dilakukan terhadap usaha dan/atau kegiatan wajib Amdal atau UKL-UPL, yang hasil produknya untuk tujuan ekspor; terdapat dalam pasar bursa; menjadi perhatian masyarakat atau pemangku kepentingan strategis, baik dalam lingkup regional maupun nasional; dan/ atau skala kegiatan signifikan untuk menimbulkan dampak terhadap lingkungan. ${ }^{54}$ Keberadaan kata "dan/atau" dalam Pasal 3 Permen Proper diartikan, bahwa kriteria Proper bersifat alternatif (pilihan).

Setelah ditetapkan sebagai peserta, perusahaan wajib menjalani pengawasan Proper sebagaimana yang telah diatur dalam Lampiran Permen Proper sebagai dasar penilaian pemeringkatan Proper. Perlu ditegaskan bahwa pengawasan yang dilakukan dalam Proper adalah pengawasan yang bersifat wajib, sehingga usaha dan/atau kegiatan yang telah

\footnotetext{
${ }^{52}$ Kriteria ketaatan Proper mencakup pemenuhan ketentuan dalam izin lingkungan: pengendalian pencemaran air; pengendalian pencemaran udara; pengelolaan limbah bahan berbahaya dan beracun (limbah B3); dan pengendalian kerusakan lingkungan hidup dalam lingkup kegiatan pertambangan. Baca lebih lanjut dalam, Indonesia, (c) Peraturan Menteri Lingkungan Hidup tentang Program Penilaian Peringkat Kinerja Perusahaan dalam Pengelolaan Lingkungan Hidup, Permen LH No. 3 2014, BN Nomor 1082 Tahun 2014, ps. 5

${ }^{53}$ Evaluasi penilaian melebihi ketaatan dilakukan terhadap delapan (8) kegiatan, yaitu sistem manajemen lingkungan; efisiensi energi; pengurangan dan pemanfaatan limbah B3; pelaksanaan pengurangan, penggunaan kembali dan daur ulang limbah padat non bahan berbahaya dan beracun (B3); penurunan emisi dan/atau gas rumah kaca; efisiensi penggunaan air dan penurunan beban pencemaran air; perlindungan keanekaragaman hayati; dan pemberdayaan masyarakat. Ibid, ps. 4 Ayat (2) butir (b) dan ps. 6 Ayat (3).

${ }^{54}$ Ibid., ps. 3 dan ps. 8
} 
ditetapkan sebagai peserta Proper tidak dapat menolak kecuali usaha dan/atau kegiatan tersebut sudah atau sedang tidak beroperasi atau sedang dalam proses penegakan hukum lingkungan.

Koesnadi menyebut Proper dengan istilah peringkat kinerja (Performance $R a$ ting). ${ }^{55}$ Dimana penilaian peringkat di- konversikan menggunakan lima warna, yaitu Emas, Hijau untuk peringkat melebihi ketaatan, Biru untuk taat, dan Merah dan Hitam untuk perusahaan tidak taat. Selengkapnya disajikan pada Tabel 1. Tujuannya agar informasi hasil penilaian yang disajikan dapat lebih mudah dipahami oleh masyarakat.

\begin{tabular}{|l|l|l|}
\hline No & Warna & Kriteria Penilaian Proper Menurut Permenlh Proper 2014 \\
\hline 1 & $\begin{array}{l}\text { Emas } \\
\text { Ka n d i - } \\
\text { dat) }\end{array}$ & $\begin{array}{l}\text { Penanggung jawab dan/atau kegiatan yang telah secara konsisten } \\
\text { menunjukkan keunggulan lingkungan hidup dalam proses pro- } \\
\text { duksi dan/atau jasa, melaksanakan bisnis yang beretika, dan ber- } \\
\text { tanggung jawab terhadap masyarakat. }\end{array}$ \\
\hline 2 & Hijau & $\begin{array}{l}\text { Penanggung jawab dan/atau kegiatan yang telah melakukan pe- } \\
\text { ngelolaan lingkungan hidup melebihi ketaatan melalui pelaksa- } \\
\text { naan sistem manajemen lingkungan, pemanfaatan sumber daya } \\
\text { secara efisien dan melakukan upaya pemberdayaan masyarakat } \\
\text { dengan baik. }\end{array}$ \\
\hline 3 & Biru & $\begin{array}{l}\text { Penanggung jawab dan/atau kegiatan yang telah melakukan upa- } \\
\text { ya pengelolaan lingkungan hidup sesuai dengan persyaratan seba- } \\
\text { gaimana diatur dalam peraturan perundang-undangan }\end{array}$ \\
\hline Merah & $\begin{array}{l}\text { Penanggung jawab dan/atau kegiatan yang upaya pengelolaan } \\
\text { lingkungan hidupnya dilakukan tidak sesuai dengan persyaratan } \\
\text { sebagaimana diatur dalam peraturan perundang-undangan }\end{array}$ \\
\hline Hitam & $\begin{array}{l}\text { Penanggung jawab dan/atau kegiatan yang sengaja melakukan } \\
\text { perbuatan atau melakukan kelalaian yang mengakibatkan pence- } \\
\text { maran atau kerusakan lingkungan serta pelanggaran terhadap per- } \\
\text { aturan perundang-undangan yang berlaku atau tidak melaksana- } \\
\text { kan sanksi administrasi. }\end{array}$ \\
\hline
\end{tabular}

Tabel 5. Peringkat Warna dan Kriteria Penilaian Proper

${ }^{55}$ Koesnadi Hardjasoemantri, Hukum Tata Lingkungan, ed. VIII, Cet. ke-19, (Yogyakarta: Gadjah Mada University Press, 2006), hlm. 298. 
Sampai sekarang, Proper telah berlangsung sebanyak 15 periode (19952019). Setiap tahunnya peserta Proper cenderung meningkat dari beragam jenis usaha dan/atau kegiatan. Perusahaan yang meraih peringkat taat, yakni biru, hijau dan emas setiap tahunnya juga cenderung meningkat. KLHK mengklaim keberhasilan Proper, pada periode 2017/2018 misalnya, KLHK mengumumkan keberhasilan terhadap penilaian aspek melebihi ketaatan, dengan nilai hasil konversi efisiensi sebesar Rp.287 Triliun. ${ }^{56}$

Setiap tahun KLHK menyelenggarakan pemberian penghargaan yang disertai penyerahan Sertifikat dan Trofi kepada peserta Proper yang meraih peringkat taat, yaitu Biru, Hijau dan Emas. Pada periode 2016-2017, 2017-2018 misalnya, penghargaan kepada perusahaan berperingkat Emas secara langsung diberikan oleh Wakil Presiden dan dilaksanakan oleh kepala daerah di daerahnya masing-masing. ${ }^{57}$ Penghargaan Proper juga dia- kui para pemangku kepentingan. Bank Indonesia misalnya, yang menetapkan penilaian Proper lingkungan menjadi persyaratan proses penilaian pemberian kredit perusahaan. ${ }^{58}$

Selama Proper berjalan masih banyak perusahaan yang meraih peringkat merah dan hitam. Menurut ketentuan Pasal 17 Permen Proper, kepada perusahaan yang meraih peringkat merah selama 2 kali akan dikenakan sanksi administrasi. Kemudian terhadap perusahaan berperingkat hitam, Menteri akan melakukan penegakan hukum lingkungan sesuai dengan ketentuan peraturan perundang-undangan.

Berdasarkan Publikasi Proper tahun 2017, diketahui sejak tahun 20145, Direktorat Penegakan Hukum Pidana (PHP) telah menindaklanjuti 47 perusahaan berperingkat hitam, dengan pengumpulan bahan keterangan (pulbaket) terhadap 21 perusahaan tahun 2014 dan 21 perusahaan tahun 2015 serta 5 perusahaan tahun $2016 .{ }^{60}$ Sayangnya pada Publikasi

\footnotetext{
${ }^{56}$ Indonesia, Kementerian Lingkungan Hidup, Publikasi Proper Periode 2017-2018

${ }^{57}$ Misalnya di Provinsi Lampung, dimana hasil penilaian Proper dibagikan secara langsung oleh Gubernur Lampung. Dalam Pemerintah Provinsi Lampung, 12 Juni 2016, http:/ / lampungprov.go.id/ berita/gubernur-beri-penghargaan-kepada-pemkabpemkot-dan-perusahaan-peduli-lingkungan.html, diakses tanggal 31 Juli 2018

${ }^{58}$ Baca Bank Indonesia, Peraturan Bank Indonesia tentang Penilaian Kualitas Aset Bank Umum dan Surat Edaran Departemen Penelitian, Per BI Nomor 14/ 15 /PBI/2012, Pasal 10 dan Pasal 11 dan Pengaturan Perbankan No. 15/28/DPNP tertanggal 31 Juli 2013, yang menetapkan Bank harus tetap memperhatikan hasil penilaian Program Proper yang dikeluarkan oleh KLHK. KLHK

${ }^{59}$ Tahun bergabungnya Kementerian Lingkungan Hidup dan Kementerian Kehutanan menjadi

${ }^{60}$ Indonesia, Kementerian Lingkungan Hidup dan Kehutanan, 2017, Laporan Hasil Publikasi Proper Periode 2016-2017. Sebelumnya, periode 2012-2013 sebanyak 17 perusahaan berperingkat hitam diproses, dimana 10 perusahaan dikenai sanksi administratif, 4 perusahaan diproses hukum dan 3 perusahaan berhasil memenuhi ketaatannya menjadi peringkat biru.
} 
Proper 2018 tidak disajikan data implementasi penegakan hukum KLHK terhadap peringkat tidak taat pada Proper periode 2016-2017. ${ }^{61}$

Sedangkan kepada perusahaan berperingkat Merah, tidak diketahui adanya sanksi yang telah diberikan. Berdasarkan kriteria Proper, maka perusahaan berperingkat merah telah melanggar ketentuan peraturan perundangan. Padahal jumlah perusahaan berperingkat merah sangatlah besar. Pada Periode 2017-2018 sebanyak 241 perusahaan berperingkat merah, periode 2016-2017 146 perusahaan, periode 2015-2016 284 perusahaan, periode 2014-2015 529 perusahaan, periode 2013-2014 516 perusahaan, dan periode 2012-2013 sebanyak 611 perusahaan. ${ }^{62}$ Diketahui KLHK mendapatkan kritik karena tidak menjatuhkan sanksi penegakan hukum yang tegas. ${ }^{63}$

\section{B. Dualisme Konteks Proper seba- gai Instrumen Penaatan Sukare- la dan Command and Control}

\section{Proper dalam Konteks Instru- men Sukarela}

Secara historis, Proper Prokasih berangkat dari keterbatasan sumber daya pemerintah untuk memaksa perusahaan mengendalikan pencemarannya. Melalui
Proper, Pemerintah berupaya memaksimalkan sumber daya untuk melaksanakan wewenang dan tanggung jawabnya dengan mendorong perusahaan secara lebih selektif, efektif dan efisien, untuk secara sukarela merealisasikan penaatan hukum, dengan memperoleh peringkat Biru (taat), yang diberikan kepada perusahaan yang telah menaati seluruh ketentuan peraturan perundangan.

Sebagaimana dijelaskan sebelumnya, maka penaatan sukarela juga dapat didasarkan atas ketiadaan penegakan hukum, sehingga penaatan hukum menjadi keputusan perusahaan yang bersifat sukarela. ${ }^{64}$ Dengan kata lain, meskipun telah tersedia ketentuan hukum yang mengatur, namun apabila tidak diiringi dengan adanya penaatan atau penegakan hukum, maka pelaksanaan kewajiban hukum adalah bentuk kesukarelaan dari subjek hukum yang bersangkutan, yaitu perusahaan.

Aspek kesukarelaan lainnya juga diimplementasikan melalui kriteria penilaian melebihi ketaatan. Dimana melalui Proper, pemerintah berupaya mendorong perusahaan yang sudah meraih peringkat biru (taat), agar secara sukarela meningkatkan kinerjanya untuk menca-

${ }^{61}$ Indonesia, Kementerian Lingkungan Hidup dan Kehutanan, 2018, Laporan Hasil Publikasi Proper Periode 2017-201.8

${ }^{62}$ Indonesia, Kementerian Lingkungan Hidup, 2015, Laporan Hasil Publikasi Proper Periode Periode 2014-2015.

${ }^{63}$ Lihat dalam Michikazu Kojima, Op.Cit., hlm. 171

${ }^{64}$ Wibisana, Op. Cit. 
pai peringkat hijau dan emas (melebihi ketaatan). Bentuk dorongan bagi perusahaan agar meraih peringkat taat dan melebihi ketaatan juga dilaksanakan melalui pemberian insentif, yang menjadi ciri dari penaatan sukarela, berupa pengakuan dari pihak ketiga serta pemberian penghargaan dan reputasi positif oleh KLHK selaku penyelenggara Proper.

Selain itu, sampai sekarang tidak terdapat adanya ketentuan peraturan perundangan yang secara eksplisit mewajibkan keikutsertaan perusahaan dalam Proper. Sementara Permenlh Proper, sebagai landasan Proper, hanya memberikan kriteria terkait perusahaan yang diikutsertakan dalam Proper. ${ }^{65}$ Tanpa adanya ketegasan bagi perusahaan untuk ikut serta dalam Proper. Sehingga, ketiadaan kewajiban memberikan hak bagi perusahaan, untuk menolak atau mengajukan keberatan apabila perusahaan yang bersangkutan ditetapkan sebagai peserta. Selain itu, sanksi atau paksaan terhadap perusahaan yang me- nolak untuk ditetapkan sebagai peserta Proper juga tidak tersedia. ${ }^{66}$

Ketiadaan ketentuan kewajiban dan sanksi, tentunya membuat KLHK tidak dapat memberikan paksaan dan/atau tindakan hukum kepada perusahaan yang menolak, meskipun telah ditetapkan sebagai peserta Proper. Dengan kata lain, maka keikutsertaan perusahaan dalam Proper merupakan bentuk "kesukarelaan" dari perusahaan yang bersangkutan. Meskipun awalnya terdapat dorongan yang kesannya "memaksa" perusahaan, melalui langkah penetapan peserta secara sepihak oleh KLHK dan/ atau Pemerintah Daerah.

Aspek lain yang mencerminkan kesukarelaan dalam Proper adalah diperbolehkannya perusahaan untuk mengajukan diri untuk menjadi peserta secara sukarela. Pada periode awal Proper tahun 1995-1997, jumlah perusahaan peserta sukarela mencapai 23 perusahaan, dari total 187 peserta Proper. Sayangnya, sejak dimulai kembali tahun 2002, sam-

\footnotetext{
${ }^{65}$ Menurut Pasal 3 Permenlh Proper, Pelaksanaan Proper dilakukan terhadap usaha dan/atau kegiatan wajib Amdal atau UKL-UPL, yang : hasil produknya untuk tujuan ekspor; terdapat dalam pasar bursa; menjadi perhatian masyarakat, baik dalam lingkup regional maupun nasional; dan/ atau skala kegiatan signifikan untuk menimbulkan dampak terhadap lingkungan hidup.

${ }^{66}$ Patut menjadi catatan adalah adanya ketentuan dalam Lampiran PerMen LH Proper yang berbunyi "Setelah peserta Proper ditetapkan, maka akan dilakukan pengawasan. Perlu ditegaskan bahwa pengawasan yang dilakukan dalam Proper adalah pengawasan yang bersifat wajib, sehingga usaha dan/ atau kegiatan yang telah ditetapkan sebagai peserta Proper tidak dapat menolak kecuali usaha dan/atau kegiatan tersebut sudah atau sedang tidak beroperasi atau sedang dalam proses penegakan hukum lingkungan." Ketentuan tersebut seolah menjadi kewajiban bagi perusahaan untuk ikut serta dalam Proper. Menurut penulis, maka kewajiban hukum (pelaksanaan pengawasan) tersebut, berlaku setelah menjadi peserta, yaitu pada kata "... telah ditetapkan sebagai peserta Proper". Bukannya kewajiban hukum bagi perusahaan untuk "menjadi peserta" Proper.
} 
pai dengan periode $2017-2018$, tidak ditemukan adanya data yang menunjukkan keikutsertaan peserta secara sukarela. ${ }^{67}$

Pemaparan di atas menunjukkan bagaimana Proper dapat digolongkan sebagai instrumen penaatan sukarela, yaitu program sukarela pemerintah (public voluntary program).

\section{Proper Dalam Konteks Com- mand and Control}

Penilaian pada aspek ketaatan untuk peringkat Biru, Merah, dan Hitam dalam Proper didasarkan atas ketaatan hukum terhadap ketentuan peraturan perundangan di bidang pengelolaan lingkung- an yang berlaku. ${ }^{68}$ Secara substansial, aspek ketaatan sebagaimana diatur dalam Pasal 5 Permen Proper tersebut, merupakan wujud dari penerapan CAC yang didasarkan atas peraturan perundangan yang berlaku (regulatory based). Menurut Publikasi KLHK, diketahui sekitar 46 peraturan telah diintegrasikan dalam kriteria penilaian Proper. ${ }^{69}$

Oleh karenanya, meskipun tanpa adanya Proper, baik perusahaan peserta maupun non peserta Proper, sesungguhnya memiliki kewajiban hukum yang sama, untuk merealisasikan berbagai kriteria yang tercakup dalam aspek ketaatan Proper. ${ }^{70}$ Perbedaannya adalah,

${ }^{67}$ Menurut Permenlh Proper 2014, maka pengaturan keikutsertaan perusahaan secara sukarela, dapat diartikan bagi perusahaan yang ada diluar ketentuan kriteria Proper sebagaimana diatur dalam Pasal 3. Mungkin ini bisa menjadi faktor minimnya partisipasi sukarela perusahaan. Namun patut dicatat, bahwa menurut ketentuan Permenlh sebelumnya, yaitu tahun Permenlh Proper tahun 2011 dan 2013 partisipasi sukarela tidak dibatasi oleh Kriteria Proper sebagaimana pengaturan Permenlh Proper 2014. Sayangnya penulis tidak dapat menemukan data dan ketentuan pengaturan dalam Permenlh pada tahun 2010, 2008, dan 2002.

${ }^{68}$ Peraturan perundangan tersebut antara lain, yaitu ketentuan perizinan lingkungan sebagaimana diatur Peraturan Pemerintah Nomor 27 Tahun 2012 tentang Izin Lingkungan, ketentuan pengendalian pencemaran air dalam PP No 82 Tahun 2001 tentang Pengelolaan Kualitas Air dan Pengendalian Pencemaran Air, ketentuan pengendalian pencemaran udara dalam Peraturan Pemerintah Nomor 41 Tahun 1999 tentang Pengendalian Pencemaran Udara, dan pengelolaan limbah B3 dalam Peraturan Pemerintah Nomor 101 Tahun 2014 tentang Pengelolaan Limbah Bahan Berbahaya dan Beracun. Sedangkan khusus untuk kegiatan pertambangan ditambahkan kriteria potensi kerusakan lahan. Baca ketentuan Pasal 5 Ayat (1) dan Ayat (2) Permenlh Proper.

${ }^{69}$ Indonesia, Kementerian Lingkungan Hidup, 2015, Publikasi Proper Periode 2014-2015.

${ }^{70}$ Misalnya ketentuan wajib pelaporan rutin yang diatur dalam Pasal 53 PP Izin Lingkungan dan Keputusan Menteri Lingkungan Hidup No. 45 Tahun 2005 tentang Pedoman Penyusunan Laporan Pelaksanaan Rencana Pengelolaan Lingkungan Hidup (RKL) dan Rencana Pemantauan Lingkungan Hidup (RPL). Ketentuan pelaporan minimal tiga bulan sekali (Laporan Triwulan) Pasal 34 PP Pengendalian Pencemaran Air mengenai upaya pengelolaan dan pemantauan dalam bidang pengendalian pencemaran air, dan laporan triwulan pengelolaan limbah B3 sebagaimana diatur dalam PP Pengelolaan Limbah B3, serta pelaporan rutin minimal enam bulan sekali (Laporan Semester) dalam upaya pengendalian pencemaran udara yang diatur dalam Pasal 50 PP Pengendalian Pencemaran Udara. Begitu pula berbagai ketentuan kinerja atau tindakan yang wajib dilaksanakan oleh perusahaan dalam pengelolaan lingkungan, antara lain seperti pemasangan sarana flow meter (alat ukur debit) pada IPAL, pencatatan debit air limbah, sarana pengambilan sampling sumber emisi udara, penyediaan berbagai sarana bangunan TPS Limbah B3, serta pemasangan titik koordinat outlet, titik koordinat Bangunan TPS Limbah B3, koordinat sumber emisi tidak bergerak (Cerobong atau Generator Listrik/Genset). 
perusahaan peserta Proper memiliki kewajiban tambahan, yaitu mendapatkan peringkat Biru, dimana perusahaan telah melakukan upaya pengelolaan lingkungan hidup sesuai dengan persyaratan sebagaimana diatur dalam peraturan perundang-undangan. Dalam konteks inilah, Proper merupakan bentuk implementasi dari instrumen CAC.

Kehadiran unsur CAC tersebut, turut berimplikasi terhadap penerapan sanksi yang juga telah diatur dalam peraturan perundangan. Namun masalahnya, Pasal 17 Permen Proper juga menetapkan pengenaan sanksi administrasi kepada perusahaan yang berperingkat Merah selama 2 kali dalam Proper. ${ }^{71}$ Dengan demikian, melalui Proper, KLHK telah mengatur kembali mekanisme penjatuhan sanksi yang baru, dengan mengesampingkan adanya pengaturan dalam peraturan perundangan yang diintegrasikan dalam kriteria penilaian Proper.

Padahal, baik UUPPLH maupun pengaturan pengendalian pencemaran air dan udara serta pengelolaan limbah B3 hanya mengenal penjatuhan sanksi administrasi apabila ditemukan adanya pelanggaran. Ketentuan Pasal 76 ayat (1) UUPPLH misalnya, yang memerintahkan penjatuhan sanksi administrasi jika dalam pengawasan ditemukan adanya pelanggaran dalam izin lingkungan. Dengan kata lain tidak dikenal adanya sanksi yang dijatuhkan apabila ditemukan pelanggaran yang "kedua kali", sebagaimana ketentuan sanksi bagi peringkat merah Proper. ${ }^{72}$

Wibisana dan Bram juga menegaskan, bahwa perusahaan yang meraih peringkat Merah dan Hitam sesungguhnya telah melanggar hukum, yang karenanya layak dijatuhi sanksi sebagaimana diatur dalam peraturan perundangan. Oleh karenanya, apabila pemerintah mengesampingkan kewenangan penegakan hukumnya, maka pemerintah seolah mengganti CAC dengan penaatan sukarela. Dengan kata lain, maka yang terjadi bukanlah dorongan penaatan me-

${ }^{71}$ Sedangkan kepada perusahaan berperingkat Hitam, sanksi disesuaikan dengan ketentuan peraturan perundangan.

${ }_{72}$ Contoh lainnya, yaitu sanksi dalam kriteria Pengelolaan Limbah Bahan Berbahaya dan Beracun (Limbah B3). Ancaman sanksi yang diatur dalam Pasal 243 dan Pasal 28 Peraturan Pemerintah Nomor 101 Tahun 2014 tentang Pengelolaan Limbah B3, mengamanatkan penjatuhan sanksi administrasi terhadap perusahaan yang tidak mentaati persyaratan lingkungan hidup dan kewajiban sebagaimana tercantum dalam izin Pengelolaan Limbah B3 untuk kegiatan Penyimpanan Limbah B3. Dengan kata lain maka persyaratan izin yang diancam sanksi administrasi adalah keseluruhannya atau $100 \%$ dari seluruh persyaratan. Bandingkan juga dengan ketentuan Lampiran IV tentang Kriteria Penilaian Proper Biru, Merah dan Hitam, maka rapor merah diberikan kepada perusahaan yang Memenuhi < $90 \%$ dari ketentuan dan persyaratan izin dan tidak ditemukan indikasi adanya pencemaran lingkungan dan/ atau gangguan kesehatan manusia. Berdasarkan hal tersebut, dapat terlihat, bahwa terdapat dualisme mekanisme pengaturan sanksi. 
lalui penaatan sukarela, tetapi dorongan untuk melakukan ketidaktaatan melalui non-enforcement. ${ }^{73}$

Namun patut dipertimbangkan, bahwa pasca berlakunya UUPPLH, wewenang penegakan hukum berupa pemberian sanksi administrasi, telah diamanatkan kepada pemerintahan daerah kabupaten/kota. Begitu pula sanksi administrasi berupa pencabutan izin lingkungan, merupakan wewenang dari pejabat pemberi izin lingkungan, yaitu kepala pemerintahan daerah. ${ }^{74}$

Bahkan, menurut Pasal 77 UUPPLH, Menteri dapat menerapkan sanksi administratif hanya jika Pemerintah menganggap pemerintah daerah secara sengaja tidak menerapkan sanksi administratif terhadap pelanggaran yang serius di bidang perlindungan dan pengelolaan lingkungan hidup. ${ }^{75}$ Dengan kata lain, secara vertikal KLHK sebaiknya bertindak jika pemerintah daerah tidak menja- lankan wewenang dan tanggung jawabnya. Oleh karena itu, penjatuhan sanksi dalam Proper yang diselenggarakan oleh KLHK seharusnya menjadi garda terakhir dalam proses penegakan hukum.

\section{Proper Dalam Konteks Instru- men Campuran (Hybrid)}

Sejak masa Proper Prokasih, Proper telah memadukan berbagai jenis instrumen penegakan hukum lingkungan. ${ }^{76}$ Sampai saat ini, Proper masih tetap menerapkan antara pendekatan CAC melalui kriteria ketaatan serta penegakan hukum dan penjatuhan sanksi administratif dan penaatan sukarela yang ditujukan untuk mendorong dilakukannya upaya swapantau dan swakelola lingkungan industri serta kriteria aspek melebihi ketaatan.

Selain itu Proper juga masih menggunakan instrumen pengungkapan informasi dengan adanya pengumuman peringkat yang menggunakan "warna"

${ }^{73}$ Lihat dalam Andri G. Wibisana, Loc. Cit., hlm. 23.

${ }^{74}$ Pasal 64 Undang-undang nomor 30 Tahun 2014 tentang Administrasi Pemerintahan yang mengatur tata cara pencabutan keputusan tata usaha negara.

75 Pasal ini menggambarkan wewenang berlapis KLHK dalam pengawasan dan penegakan hukum, melalui second line enforcement atau supervisi (oversight) terhadap pemerintah daerah yang secara sengaja tidak menerapkan sanksi administrasi atas pelanggaran serius yang terjadi. Baca lebih lanjut dalam Raynaldo Sembiring, et. al., Anotasi Undang-Undang Nomor 32 tentang Perlindungan dan Pengelolaan Lingkungan Hidup, Jakarta : Indonesian Center for Environmental Law (ICEL), 2014

Selain itu, menurut Menurut Prof. Asep Warlan Yusuf, pengawasan yang efektif adalah pengawasan berlapis. Lapis yang pertama (lini kesatu) dilakukan oleh Pemberi izin baik pada tingkat pusat, provinsi atau kabupaten/kota. Apabila lapis pertama tidak berhasil (gagal) menjalankan tugasnya sesuai yang dimandatkan oleh peraturan perundangan, pengawasan dilanjutkan dengan lapis kedua (lini kedua) yang dilakukan oleh Menteri (KLHK). Dalam pelaksanaannya Menteri dapat mendekonsentrasikan kepada Gubernur sebagai Kepala Daerah Pemerintah Provinsi.

${ }^{76}$ Bapedal, 1995, Proper Prokasih (Sebagai Perwujudan Aspek Penaatan Lingkungan Dalam Rangka Program Kali Bersih), Pusat Pengembangan Informasi dan Penaatan Lingkungan Bapedal, hlm.2-3. 
yang dapat meningkatkan kepedulian dan partisipasi masyarakat serta instrumen ekonomi melalui pemberian insentif berupa penghargaan atau reputasi positif. Skema pengungkapan informasi inilah, yang menjadi salah satu kewajiban tambahan bagi para peserta Proper. ${ }^{77}$

Penerapan berbagai instrumen penegakan hukum lingkungan dalam Proper, melalui sistem hybrid yang menggabungkan lebih dari satu instrumen memang diketahui lebih efisien untuk diterapkan. ${ }^{78}$ Keterpaduan berbagai instrumen dalam Proper diharapkan meningkatkan kinerja dalam mewujudkan pengelolaan lingkungan oleh perusahaan secara optimal.

Dapat dikatakan tidak ada instrumen tunggal yang dapat digunakan untuk menghadapi seluruh permasalahan lingkungan. Lebih khusus lagi, karena masing-masing pendekatan memiliki kelebihan dan kelemahannya masing-masing, sehingga kombinasi mungkin diperlukan (yang juga dapat sering ditemukan dalam praktik kebijakan), yang idealnya dapat memanfaatkan secara optimal keuntungan dari setiap instrumen kebijakan. ${ }^{79}$

Namun, penerapan campuran kebijakan tersebut telah menimbulkan kebingungan untuk menentukan jenis instrumen yang menjadi dasar pelaksanaan Proper. Menurut Faure patut diingat, bahwa campuran instrumen kebijakan berpotensi ditentukan oleh pilihan politik dan/atau kelompok kepentingan. ${ }^{80}$ Ke depannya, mungkin diperlukan adanya ketegasan terhadap jenis instrumen yang menjadi dasar Proper, sebagai landasan teoretis untuk membangun dan/ atau meningkatkan Proper secara konstruktif dan akuntabel.

\section{Dilema Penerapan Sanksi Dalam Proper}

\section{Penegakan Hukum Non Peserta Proper}

Selama Proper berjalan, masih banyak perusahaan yang meraih peringkat merah dan hitam. Keikutsertaan perusahaan dalam proper merupakan bentuk komitmen perusahaan menaati ketaatan hukum, atau bahkan melebihi ketaatan dan/atau kewajiban hukum perusahaan dalam pengelolaan lingkungan. ${ }^{81}$ Perta-

${ }_{77}$ Pengumuman peringkat Proper pada prinsipnya sama dengan pengumuman hasil pengawasan oleh pemerintah terhadap kinerja pengelolaan lingkungan perusahaan. Namun untuk perusahaan non peserta Proper, maka pemerintah tidak berwenang untuk mempublikasikan hasil pengawasannya. Sedangkan melalui Program Proper, maka pemerintah memiliki wewenang untuk mempublikasikan kinerja para peserta Proper, dengan menggunakan skema "warna".

${ }_{78}^{78}$ Michael Faure, Marjan Peeters et al, Loc. Cit., Michael Faure, Nicole Niessen, Loc. Cit., hlm. 224.

${ }^{79}$ Michael Faure, "Designing Incentives Regulation for the Environment," Maastricht Faculty of Law Working Paper (2008/7); Baca juga Andri G. Wibisana, 2019, Op.Cit.

${ }^{80}$ Michael Faure, Op.Cit.

${ }^{81}$ Matthew Potoski, Aseem Prakash, Covenants with Weak Swords: ISO 14001 and Facilities> Environmental Performance, Journal of Policy Analysis and Management, Vol. 24, No. 4 (Fall, 2005), pp. 745-769. 
nyaan utamanya adalah, apakah perusahaan yang tidak mengikuti Proper telah memenuhi ketaatan hukum?

Pada periode 2017-2018, jumlah peserta Proper mencapai 1906 perusahaan Sedangkan dalam rangka pembinaan dan pengawasan ketaatan hukum yang bersifat wajib, maka jumlah tersebut jauh dari kondisi ideal. Menurut Publikasi Proper 2009, diperkirakan terdapat 8.000-10.000 perusahaan yang berpotensi menjadi peserta Proper. ${ }^{82}$ Sedangkan, menurut data BPS di tahun 2015, diketahui jumlah perusahaan industri besar dan sedang yang terdapat di Jawa dan Luar Jawa mencapai 26.322 perusahaan. ${ }^{83}$

Patut dipertimbangkan, bahwa nomenklatur "signifikan untuk menimbulkan dampak terhadap lingkungan" dalam kriteria peserta Proper adalah istilah baru yang dapat menimbulkan beragam penafsiran secara luas. Istilah umum yang digunakan dalam peraturan perundangan lingkungan mengacu pada kata "penting" atau "dampak penting", 84 bukannya istilah "signifikan". Sayangnya tidak diketahui alasan KLHK menggunakan nomenklatur yang menimbulkan berbagai penafsiran tersebut. Padahal menurut kamus besar bahasa indonesia (KBBI) salah satu arti kata signifikan adalah "penting". ${ }^{85}$

KLHK juga tidak menetapkan ketentuan lebih lanjut, misalnya, apakah kriteria tersebut diukur dari "kapasitas produksinya" atau "kuantitas dan kualitas pencemaran yang ditimbulkannya". Sehingga ketentuan tersebut cenderung bersifat diskresioner, ${ }^{86}$ dimana penafsirannya didasarkan atas wewenang Tim

\footnotetext{
${ }^{82}$ Indonesia, Kementerian Lingkungan Hidup, 2009, Publikasi Proper Periode 2008-2009

${ }_{83}$ BPS, data Jumlah Industri Pengolahan Besar dan Sedang, Jawa dan Luar Jawa, 2001-2015, https://www.bps.go.id/statictable/2010/01/18/1053/jumlah-industri-pengolahan-besar-dan-sedang-jawa-dan-luar-jawa-2001-2015.html, diakses tanggal 22 Januari 2018.

Sementara jumlah industri skala kecil pada tahun 2014-2014 yang berpotensi menimbulkan pencemaran jumlahnya mencapai 284.501- 531,351 perusahaan. Sedangkan menurut penelitian oleh USAID, pada tahun 2004 saja estimasi perusahaan skala kecil yang berpotensi berdampak terhadap air permukaan dan air tanah dalam mencapai 134,000 perusahaan, dengan estimasi peningkatan sebanyak $14 \%$ setiap tahunnya dari data 2001. Lihat dalam USAID, ICEL, Et.Al., 2008, Environmental Compliance and Enforcement in Indonesia Rapid Assessment, sumber : https://www.aecen.org/sites/default/files/ID_Assessment.pdf, diakses 14 Juli 2018; Indonesia, Kementerian Perindustrian, Data tahun 2014, http://www.kemenperin.go.id/jawaban_attachment.php?id=6000\&id_t=21781, diakses tanggal 20 januari 2019

${ }^{84}$ Misalnya saja penentuan kriteria yang telah ditetapkan dalam Peraturan Menteri Negara Lingkungan Hidup dan Kehutanan Nomor 38 Tahun 2019 tentang Jenis Rencana Usaha Dan/Atau Kegiatan Yang Wajib Memiliki Analisis Mengenai Dampak Lingkungan Hidup.

${ }^{85}$ Lihat https:// kbbi.web.id/signifikan, diakses pada tanggal 8 Maret 2020.

${ }^{86}$ Menurut Pasal 1 Butir 9 Undang-undang Nomor 30 Tahun 2014 tentang Administrasi Pemerintahan, Diskresi adalah Keputusan dan/atau Tindakan yang ditetapkan dan/atau dilakukan oleh Pejabat Pemerintahan untuk mengatasi persoalan konkret yang dihadapi dalam penyelenggaraan pemerintahan dalam hal peraturan perundang-undangan yang memberikan pilihan, tidak mengatur, tidak lengkap atau tidak jelas, dan/atau adanya stagnasi pemerintahan.
} 
Proper atau KLHK. Ketidakjelasan tersebut semakin membuat keragaman kriteria peserta Proper yang telah bersifat "alternatif", menjadi semakin luas dan cenderung "abu-abu". ${ }^{87}$ Padahal, tanpa kriteria yang terukur, akan berpotensi menimbulkan pelanggaran prinsip persamaan di hadapan hukum (equality before the law).

Ketiadaan peserta sukarela dalam Proper, menjadi indikasi keengganan perusahaan ikut serta dalam Proper. Secara rasional, perusahaan yang tidak taat atau melalaikan kewajiban hukumnya, akan mencari cara untuk menyembunyikan pelanggarannya. Perusahaan seperti itu, tidak akan bersedia menjadi peserta dalam Proper. Dalam perspektif persoalan barang milik bersama secara teoretis dinyatakan, bahwa individu yang rasional dan mementingkan diri sendiri tidak akan berkontribusi terhadap barang publik atau upaya konservasi sumber daya milik bersama. ${ }^{88}$

Ketidakberdayaan penegakan hukum dan ketidaktaatan terlihat dalam implementasi ISPO untuk industri kelapa sawit. Dimana sejak tahun 2011 Pemerintah selalu memperpanjang jangka waktu sertifikasi ISPO karena ketidaktaatan perusahaan. ${ }^{89}$ Ancaman sanksi berupa peringatan, penurunan kelas kebun dan/atau pencabutan izin tak terdengar jejaknya. Alih-alih pemerintah berupaya menerbitkan Perpres baru, yang diduga sekadar memperpanjang jangka waktu sertifikasi.

Apabila dikaitkan dengan konteks historis Proper, penegakan hukum di Indonesia dan peranan penaatan sukarela di negara berkembang, maka dapatlah kita berasumsi, bahwa perusahaan yang tidak mengikuti Proper adalah perusahaan yang "patut dicurigai" tidak taat hukum dan patut dijatuhi sanksi. Freeport misalnya, sebagai salah satu perusahaan tambang emas terbesar di dunia, diketahui memiliki rekam jejak tidak taat dengan mendapatkan peringkat hitam. Namun, sampai saat ini tidak diketahui alasan Freeport tidak kembali terdaftar

\footnotetext{
${ }^{87}$ Baca Subbab Implementasi dan Perkembangan Proper.

${ }^{88}$ Bruno S. Frey, Alois Stutzer, "Environmental Morale and Motivation, Institute for Empirical Research in Economics" University of Zurich," Working Paper No. 288 (2006).

${ }^{89}$ Awalnya, Permentan ISPO No.19/2011 menetapkan batas waktu sertifikasi sampai dengan 31 Desember 2014. Lalu diperpanjang sampai dengan Maret 2017 melalui Permentan ISPO No.11/2015. Setelah Sewindu berlalu, pada tahun 2019 baru 457 perusahaan tersertifikasi, dari sekitar 2.000-an perusahaan. Sedangkan diasumsikan terdapat 3 juta ha luasan lahan tersertifikasi, dari total 14 juta Ha lahan. Lihat dalam Ispo, http://www.ispo-org.or.id/index.php?option=com_content\&view=article\&id=114\&Itemid=279\&lang=ina, diakses pada tanggal 22 Agustus 2019

${ }^{90}$ Laode M. Syarif dan Kadek Sarna, Permasalahan Lingkungan yang Penting, dalam Laode M. Syarif, Andri G. Wibisana, Hukum Lingkungan, Teori, Legislasi dan Studi Kasus, (2013) hlm. 28.
} 
dalam Proper. ${ }^{90}$

Selain itu, tidak diketahui adanya sistem pengawasan dan penegakan hukum yang telah dijalankan oleh Pemerintah atau Pemerintah Daerah terhadap non peserta Proper. Sampai saat ini tidak terdapat publikasi implementasi pengawasan terhadap non peserta proper. Akibatnya ketidaktaatan hukum non peserta tidak diketahui, sehingga sanksi hukum menjadi sekadar angan-angan belaka. Padahal ketiadaan sistem pengawasan dan sanksi telah menimbulkan potensi terjadinya ketidaktaatan atau pencemaran lingkungan. ${ }^{91}$ Meskipun harus dikaji lebih lanjut secara empiris, namun ketiadaan sistem pengawasan dan sanksi telah menimbulkan potensi ketidaktaatan dan timbulnya pencemaran oleh non peserta Proper. Karenanya, KLHK harus mempertimbangkan penegakan hukum dalam kerangka yang lebih luas, yang mencakup peserta dan non peserta
Proper.

\section{Ketidakadilan Penerapan Sanksi antara Peserta dan Non Peserta Proper}

Keikutsertaan dalam Proper adalah bentuk komitmen perusahaan menaati ketaatan hukum. Dimana peserta secara proaktif telah memberikan data dan informasi yang diperlukan dalam proses penilaian Proper.

Perusahaan yang meraih peringkat tidak taat dalam Proper, telah bekerja sama untuk mengungkapkan informasi tentang pelanggaran hukum yang telah dilakukannya (mungkin karena ketidaksengajaan) kepada pemerintah melalui tim penilai Proper. Terungkapnya pelanggaran oleh perusahaan tentunya menimbulkan perhatian para pemangku kepentingan.

Sedangkan terhadap non peserta, keterbatasan sumber daya yang dimiliki oleh pemerintah dan minimnya kema-

\footnotetext{
${ }^{91}$ Gagasan bahwa pengawasan dapat memengaruhi kepatuhan didasarkan pada asumsi pilihan rasional tentang kecemasan akan ditangkap atau ketakutan di masa depan. Sebagai contoh, Laplante dan Rilstone (1996) menemukan bahwa inspeksi memiliki efek positif yang kuat pada bagaimana perusahaan melaporkan data lingkungan yang diperlukan. Dasgupta, Hettige, dan Wheeler (2000) menemukan bahwa tekanan regulasi yang dirasakan meningkatkan kemungkinan bahwa perusahaan akan mengadopsi inisiatif lingkungan sukarela unilateral. Dengan demikian, semakin pasti pelanggaran akan ditemukan dan kemudian dihukum, semakin kecil kemungkinan bahwa pelaku akan melanggar hukum. Meskipun tingkat inspeksi yang relatif tinggi dapat ditafsirkan sebagai peningkatan probabilitas bahwa setiap pelanggaran yang ada akan terdeteksi, tingkat inspeksi yang relatif rendah dapat diartikan sebagai penurunan probabilitas bahwa setiap pelanggaran yang ada akan terdeteksi. Memang, penelitian terdahulu tentang pelaporan diri menunjukkan bahwa ketika fasilitas diperiksa, mereka lebih mungkin untuk menyerahkan laporan pemantauan pembuangan yang disyaratkan EPA (Magat dan Viscusi, 1990: 354). Baca dalam Paul B. Stretesky, Corporate Self-Policing And The Environment, Criminology Volume 44 Number 3 (2006); Kjetil Telle, "The threat of regulatory environmental inspection: impact on plant performance," Journal of Regulatory Economics, Vol. 35:154-178 (2009).
} 
uan politik telah mengakibatkan pemerintah tidak dapat merealisasikan suatu sistem yang dapat memantau seluruh perusahaan, yaitu peserta dan non peserta Proper. Ketiadaan sistem pengawasan non peserta Proper telah memberikan keleluasaan non peserta untuk terbebas dari pengawasan dan ancaman sanksi penegakan hukum sebagaimana dihadapi peserta Proper.

Ketidakadilan terasa antara peserta dan non peserta Proper. Pemerintah seolah-olah terlihat hanya memfokuskan penegakan hukum terhadap peserta Proper. Selain itu, sebagaimana dibahas sebelumnya, maka kriteria peserta yang diatur dalam Permenlh Proper sangat luas dan abu-abu. Sehingga sangat bergantung kepada kewenangan diskresioner dari KLHK selaku penyelenggara Program dalam menetapkan status kesertaan dalam Proper. Misalnya terlihat dari ketidakjelasan tindakan KLHK yang tidak mengikutsertakan Freeport atau jenis usaha Hotel dan Rumah Sakit. ${ }^{92}$ Hal tersebut sangat berpotensi melanggar prinsip equality before the law.

Padahal menurut Potoski dan Prakash, menjatuhkan sanksi hukum yang sama, antara pelanggaran yang diung- kapkan sendiri dan yang ditemukan melalui pemantauan atau inspeksi pemerintah akan berpotensi mengurangi insentif terhadap itikad baik perusahaan untuk mencapai ketaatan hukum. ${ }^{93}$ Sebagai gambaran, pada kasus perusahaan Adolph Coors, langkah self-audit perusahaan menemukan, bahwa emisi udara markasnya di Colorado melampaui ketentuan pedoman EPA. Ketika perusahaan secara sukarela mengungkapkan pelanggaran yang ditemukan dan mengembangkan rencana kepatuhan, kemudian didenda hampir \$ 1 juta oleh Pemerintah Colorado. Kasus tersebut menunjukkan, bahwa melalui tuntutan agresif kepada perusahaan yang mengidentifikasi pelanggaran mereka sendiri, maka pemerintah telah mencegah implementasi self-audit oleh perusahaan. ${ }^{94}$

Tentunya perusahaan yang meraih peringkat tidak taat akan "lebih aman" untuk tidak mengungkapkan pelanggarannya melalui keikutsertaannya dalam Proper. Alih-alih mendapatkan penghargaan, peserta yang menunjukkan komitmen kerja samanya hanyalah dihadapkan pada ancaman sanksi. Perusahaan tentu tidak ingin mendapatkan reputasi negatif dari pemangku kepentingan,

${ }^{92}$ Padahal banyak dijumpai kasus pembuangan Limbah B3 sisa kemasan medis dari Rumah Sakit. Misalnya, lihat artikel Sudirman Wamad, «34 Rumah Sakit Diduga Buang Limbah Medis di Cirebon», Kamis 14 Desember 2017, sumber https://news.detik.com/berita-jawa-barat/d-3770128/34-rumahsakit-diduga-buang-limbah-medis-di-cirebon, diakses tanggal 1 Agustus 2018.

${ }_{93}$ Matthew Potoski and Aseem Prakash, 2011, Loc.Cit., hlm. 85.

${ }^{94}$ Paul B. Stretesky, Op.Cit. 
apalagi ancaman sanksi dari pemerintah. Sehingga peserta akan termotivasi mengikuti jejak non-peserta, yang patut diduga tidak taat. Wajarlah, jika nantinya perusahaan mempertimbangkan sikap kerja samanya kemudian memutuskan keluar dari program Proper.

\section{Keberlangsungan Proper dan Penerapan Sanksi}

KLHK menghadapi dilema, dimana harus memilih untuk memberikan sanksi terhadap peserta Proper atau menjaga eksistensi dan keberlangsungan Proper. Besarnya jumlah perusahaan berperingkat tidak taat menimbulkan kekhawatiran KLHK untuk meminta pertanggungjawaban peserta dan mendokumentasikan hasil (yang buruk) dalam program yang sekarang menjadi andalannya. Padahal, Pemerintah selaku sponsor mungkin berupaya untuk terus mencari peserta dan menunjukkan hasil yang baik jika ingin mempertahankan keberlangsungan Programnya. ${ }^{95}$ Mungkin inilah alasan dibalik tindakan dikeluarkannya Hotel dan Rumah Sakit, yang banyak meraih peringkat Merah dan Hitam pada Proper 2013-2014 dan 2014-2015. ${ }^{96}$ Akibatnya, melalui Proper pemerintah telah mendorong ketidaktaatan dengan tindakan tidak menjatuhkan sanksi kepada peserta yang berperingkat tidak taat.

Memang, penerapan sanksi dalam Proper dapat menjadi insentif atau pendorong bagi perusahaan untuk merealisasikan sekaligus mempertahankan kinerja penaatan hukumnya. ${ }^{97}$ Tetapi, penerapan sanksi administrasi dan sanksi penegakan hukum kepada perusahaan berperingkat merah dan hitam yang diatur dalam Pasal 17 Permenlh Proper ${ }^{98}$ hanyalah salah satu dari berbagai faktor yang mendorong penaatan hukum oleh perusahaan. ${ }^{99}$ Sebaliknya, penerapan sanksi mungkin dapat menimbulkan tekanan terhadap kesukarelaan perusahaan untuk terus berpartisipasi dalam Proper.

Terkait motivasi, maka perlu mempertimbangkan penerapan teori crowding out. Dimana langkah peningkatan terhadap motivasi eksternal (sanksi) mungkin

95 Thomas P. Lyon, John W. Maxwell, Corporate Environmentalism and Public Policy, (Cambridge University Press, 2004), hlm. 170.

${ }^{96}$ Pada Proper 2015-2016 dan 2016-2017, jenis usaha Hotel dan Rumah Sakit yang banyak meraih peringkat tidak taat, tidak diikutsertakan kembali menjadi peserta Proper.

${ }_{97}$ Manfaat sanksi dalam penaatan sukarela lihat dalam Anna Alberini,Kathleen Segerson, Assessing Voluntary Programs to Improve Environmental Quality, Environmental and Resource Economics 22: 157-184, 2002

${ }^{98}$ Baca kembali penerapan sanksi Proper dalam Bab sebelumnya, dalam sub bab A.3 berjudul "Penerapan Sanksi Peserta Proper"

${ }_{99}$ Bruno S. Frey, Yuval Feldman, "Five Models of Regulatory Compliance Motivation Empirical Findings and Normative Implications, Bar-Ilan University Public Law and Legal Theory," Working Paper No. 12-10 (2010).

100 Ibid. 
menghasilkan ketaatan hukum yang tidak sesuai harapan. ${ }^{100}$ Karenanya akan lebih baik untuk mewujudkan penegakan hukum terhadap non peserta Proper dan kemudian menerapkan sanksi berupa audit wajib/penyebaran dan strategi pengungkapan informasi yang bersifat meningkatkan motivasi internal bagi peserta program sukarela.

KLHK dapat pula mengambil pelajaran dalam kasus kebakaran hutan. Meskipun KLHK memenangkan gugatan, namun perbaikan lingkungan tidak terealisasi. ${ }^{101}$ Berdasarkan pemaparan tersebut, maka pemberian sanksi sebagai disinsentif perusahaan yang tidak taat agar meningkatkan kinerjanya menjadi taat dalam Proper, layak dipertimbangkan kembali.

\section{Penutup}

Keterbatasan pemerintah seharusnya mendorong pengalokasian sumber daya secara bijaksana. Kehadiran sanksi sebagai pendorong motivasi yang bersifat eksternal bukanlah satu-satunya upaya untuk meningkatkan kinerja perusahaan dalam penaatan sukarela. Sebaliknya, mungkin penggunaan tongkat (stick) dapat melemahkan kesukarelaan perusa- haan, sehingga secara kumulatif dapat mengancam keberlangsungan Proper.

Sudah saatnya bagi KLHK untuk merevisi Proper dengan menegaskan jenis instrumen yang menjadi landasan Proper, apakah atas kesukarelaan ataukah CAC. Sehingga konstruksi Proper dapat dibangun secara teoritis dan lebih optimal. KLHK juga dapat bersikap lebih kooperatif, dengan merestrukturisasi kembali mekanisme penerapan sanksi dalam penyelenggaraan Proper. Tentunya dengan tetap selaras atau tidak bertentangan dengan ketentuan peraturan perundangan (CAC).

Harapannya adalah Pemerintah akan semakin menghemat sumber daya yang dikeluarkan untuk penegakan sanksi CAC terhadap peserta Proper. Sumber daya tersebut kemudian didayagunakan untuk merealisasikan sistem penegakan hukum terhadap non-peserta Proper. Dengan demikian desain Proper telah diletakkan pada kerangka kebijakan yang lebih luas, mencakup pertimbangan penaatan hukum terhadap non-peserta Proper.

Proper dapat meningkatkan motivasi internal perusahaan atau manajer perusahaan melalui pemberian "wor-

${ }^{101}$ Menurut data ICEL, dari 8 gugatan perdata Karhutla total nilai ganti rugi mencapai $\pm 2,7$ triliun rupiah. Sayangnya belum ada satupun putusan tersebut yang dieksekusi oleh Pengadilan. Sehingga tindakan pemulihan yang dilakukan sebagai bagian dari eksekusi putusan belumlah terwujud, baca dalam ICEL, Catatan Awal Tahun 2019: “Narasi Yang Hilang Dalam Proyeksi Kebijakan Lingkungan Hidup Capres-Cawapres", 2019. 
tel" dalam upaya mendorong kinerja perusahaan. Ketidaktaatan dapat terjadi karena ketidaktahuan. Karenanya perubahan perilaku dapat didorong dengan memberikan insentif, berupa informasi atau publikasi untuk meningkatkan kinerja pengelolaan lingkungan. ${ }^{102}$ Pemberian wortel melalui subsidi, pelatihan audit atau manajemen lingkungan dapat menjadi pelengkap yang bermanfaat di negara berkembang dimana penegakan hukumnya lemah. ${ }^{103}$

KLHK seharusnya mampu membuktikan klaim keberhasilan Proper mencapai keuntungan atau efisiensi melalui implementasi pengelolaan lingkungan. ${ }^{104}$ Perusahaan tentunya tidak akan menolak, apabila potensi keuntungan yang dapat dicapai melalui Proper adalah benar adanya. Sehingga tanpa ancaman sanksi hukum, KLHK seharusnya dapat dengan mudah mengajak sebanyak mungkin perusahaan untuk berpartisipasi dalam Proper, sekaligus merealisasikan tindakan "nonregret" yang di klaim menguntungkan perusahaan, dengan meraih peringkat taat dan melebihi ketaatan. ${ }^{105}$

Keterbatasan data yang mengandalkan Publikasi Proper KLHK mengakibatkan kesulitan mengkaji secara lebih mendalam mekanisme penerapan sanksi dalam Proper. Sebab Publikasi KLHK tidak menyajikan secara mendetail data terkait keluar dan masuknya peserta dalam Proper, penerapan sanksi terhadap peringkat Merah dan hasil penegakan hukum yang telah dilaksanakan.

${ }^{102}$ Lihat juga dalam Allen, Blackman. Shakeb, Afsah. “How Do Public Disclosure Pollution Control Programs Work? Evidence from Indonesia", Discussion Paper, Resources for the Future, 00-44, Washington DC., (2000).

KLHK dapat bekerja sama dengan pihak universitas, untuk ikut serta membantu menyediakan informasi dan bersama-sama perusahaan berusaha mencapai sistem pengelolaan lingkungan yang optimal. Baik melalui publikasi dan pembagian pedoman pengelolaan lingkungan, pelatihan, workshop, seminar, dan/atau lokakarya.

${ }^{103}$ Dasgupta, et.al., "What Improves Environmental Compliance? Evidence from Mexican Industry," Journal of Environmental Economics and Management, Vol. 39, Issue 1, (January 2000), hlm. 39-66.

Tekanan non-regulasi yang diberikan oleh para pemangku kepentingan misalnya, sedikit atau banyaknya tetap dapat menambah motivasi perusahaan, meskipun penegakan hukum lemah. Misalnya pemberian subsidi atau pinjaman berbunga rendah untuk peralatan pencegahan pencemaran dan tekanan teman sebaya dan penduduk sekitar, dan/atau penerapan strategi pengungkapan informasi untuk citra/reputasi perusahaan, sebagaimana telah dipraktikkan pada masa awal Proper (Proper Prokasih). Namun akan tergantung pada, bagaimanakah implementasi pengungkapan informasi (information disclosure) dalam Proper.

${ }^{104}$ Baca kembali sub bab "Implementasi dan Perkembangan Proper", dimana kinerja efesiensi yang dicapai dalam perusahaan peserta Proper tahun 2017-2018 sebanyak 287 triliun.

${ }^{105}$ Baca juga dalam Lee, dimana beberapa ahli telah membuktikan, bahwa "kegagalan organisasi" akibat kurangnya sumber daya dan/ atau informasi yang relevan bertanggung jawab atas buruknya penilaian perusahaan terhadap proses produksi dan pengelolaan lingkungan. Baca ulasan pemberian informasi untuk tindakan nonregret atau tanpa penyesalan dalam Eungkyoon Lee, Information Disclosure and Environmental Regulation: Green lights and Gray Areas, Regulation And Governance, Vol. 4 No. 3, (2010), p. 303-328 


\section{DAFTAR PUSTAKA}

\section{Peraturan perundang-undangan}

Indonesia, Undang-Undang Nomor 32

Tahun 2009 tentang Perlindungan dan Pengelolaan Lingkungan Hidup. Peraturan Bank Indonesia Nomor 14/ 15 /PBI/2012 tentang Penilaian Kualitas Aset Bank Umum Peraturan Menteri Lingkungan

Hidup Nomor 16 Tahun 2012 tentang Penyusunan Dokumen Lingkungan Hidup.

Peraturan Menteri Lingkungan Hidup Nomor 2 Tahun 2014 tentang Pencantuman Logo Ekolabel. Peraturan Menteri Lingkungan

Hidup Nomor 3 Tahun 2014 tentang Program Penilaian Peringkat Kinerja Perusahaan Dalam Pengelolaan Lingkungan (Permenlh Proper).

Peraturan Menteri Lingkungan

Hidup dan Kehutanan Nomor 38

Tahun 2019 tentang Jenis Rencana Usaha dan/atau Kegiatan Yang Wajib Memiliki Analisis Mengenai Dampak Lingkungan Hidup.

, Keputusan Menteri Lingkungan

Hidup Nomor: Kep- 35 A/ MENLH/7/1995 tentang Program Penilaian Kinerja Perusahaan/ Kegiatan Usaha Dalam Pengendalian Pencemaran Dalam Lingkup Kegiatan Prokasih (Proper Prokasih) Surat Edaran Departemen Penelitian dan Pengaturan Perbankan No. 15/28/ DPNP tertanggal 31 Juli 2013 perihal Penilaian Kualitas Aset Bank Umum.

\section{Buku}

Adelman, David E., Climate Change, Federalism, and Promoting Technological Change. dalam Flournoy, Alyson C. Driesen, David M. (editor). Beyond Environmental Law, Policy Proposals For A Better Environmental Future, Cambridge University Press. 2010.

Bruijn, Theo de, Vicki Norberg-Bohm. Innovations in the Environmental Policy System: Voluntary, Collaborative and Information-Based Policies in the United States and the Netherlands dalam Weber, Matthias. Hemmelskamp, Jens. Towards Environmental Innovation Systems, Springer, 2005,

Carraro, Carlo, Francois Leveque. “The rationale and potential of voluntary approaches", dalam Carlo Carraro, Francois Leveque (eds), Voluntary Approaches in Environmental Policy, Kluwer Academic Publishers, Dordrecht, The Netherlands, 1999.

Farmer, Andrew. Handbook of Environmental Protection and Enforcement, Principle and Practice, London: Routledge, 2007.

Faure, Michael, Marjan Peeters, Andri G Wibisana. "Economic Instruments: Suited to Developing Countries?", dalam Michael Faure dan Nicole Niessen (eds.), Environmental Law in Development: Lessons From The Indonesian Experience, Edward Elgar, Cheltenham UK, 2006. 
Fiorino, Daniel J., The New Environmental Regulation, England: The MIT Press, 2006.

Hardjasoemantri, Koesnadi. Hukum Tata Lingkungan, ed. VIII, Cet. ke-19, Yogyakarta: Gadjah Mada University Press, 2006.

Iannuzzi, Al Jr., Industry Self-Regulation and Voluntary Environmental Compliance, United States: CRC Press, 2002.

Kojima, Michikazu. "Rating Programme Revisited: In the Case of Indonesia", dalam Tadayoshi Terao, Kenji Otsuka, Development of Environmental Policy in Japan and Asian Countries, Palgrave Macmillan, 2007.

Kolb, Robert W. Encyclopedia of business ethics and society, Sage Publication, 2008.

Kementerian Lingkungan Hidup, Sekilas Proper, Dulu, Sekarang dan Masa Mendatang, Deputi Bidang Dampak Pengendalian Sumber Institusi, 2005.

Kementerian Lingkungan Hidup dan Kehutanan, Laporan Hasil Publikasi Proper Periode 2017-2018, Jakarta 2018.

Laporan Hasil Publikasi Proper Periode 2016-2017, Jakarta 2017.

Laporan Hasil Publikasi Proper Periode 2014-2015, Jakarta 2015.

Laporan Hasil Publikasi Proper Periode 2008-2009, Jakarta 2009.

Lyon, Thomas P. John W. Maxwell. Corporate Environmentalism and Public Policy, Cambridge University Press, 2004.
OECD, Voluntary Approaches for Environmental Policy: An Assessment, (Paris, OECD, 1999) hlm.8

Potoski, Matthew., Aseem Prakash., Voluntary Programs, Compliance and The Regulation Dilemma, dalam Levi-Faur, David. Handbook on the Politics of Regulation, USA: Edward Elgar, 2011.

Sembiring, Raynaldo. et. al., Anotasi Undang-Undang Nomor 32 tentang Perlindungan dan Pengelolaan Lingkungan Hidup, Jakarta: Indonesian Center for Environmental Law (ICEL), 2014

Sullivan, Rory. Rethinking Voluntary Approaches in Environmental Policy, (London: Edward Elgar, 2005)

Syarif, Laode M, Kadek Sarna. Permasalahan Lingkungan yang Penting, dalam Laode M. Syarif, Andri G. Wibisana, Hukum Lingkungan, Teori, Legislasi dan Studi Kasus, 2013.

Worthington, Ian. Greening Business, Research, Theory, and Practice, (United Kingdom: Oxford University Press), 2013.

\section{Artikel jurnal/media massa}

Afsah, Shakeb, Benoit Laplante, Nabiel Makarim. Programme-Based Pollution Control Management: The Indonesian PROKASIH Programme. World Bank Policy Research Working Paper No. 1602, 1996

Afsah, Shakeb, Benoit Laplante, David Wheeler. "REGULATION IN THE INFORMATION AGE Indonesian 
Public Information Program for Environmental Management." Conference Proceedings, (1997).

Alberini, Anna, Kathleen Segerson. Assessing Voluntary Programs to Improve Environmental Quality, Environmental and Resource Economics, 22: 157-184, 2002.

Blackman, Allen. Can Voluntary Environmental Regulation Work in Developing Countries? Lessons from Case Studies, The Policy Studies Journal, Vol. 36, No. 1, 2008;

\section{Voluntary Environmental}

Regulation in Developing Countries (Fad or Fix?), Resources for the Future (RFF) Discussion Paper (DP), 07-10, 2007

Blackman, Allen. Shakeb Afsah. "How Do Public Disclosure Pollution Control Programs Work? Evidence from Indonesia", Discussion Paper (DP), 00-44, Washington, DC, Resources for the Future, 2000.

Blackman, Allen, Uribe Eduardo, Hoof Bart van, dan Lyon Thomas P., Voluntary Environmental Agreements in Developing Countries-The Colombian Experience, Resources For Future (RFF), D P 12 - 0 6, Februari 2012

Coglianese, Cary, Jennifer Nash. Motivating Without Mandates: The Role of Voluntary Programs in Environmental Governance, (2016). Faculty Scholarship. Paper 1647;

Cole, Daniel H. Explaining the Persistence of 'Command-and-Control' in US Environmental Law, Legal Studies Research Paper Series, No. 380, 2017.
Cunningham, James A., Free riders and environmental voluntary approaches, Progress in Industrial Ecology, An International Journal, Vol. 3, No. 5, 2006.

Darnall, Nicole, Matthew Potoski. Sponsorship matters: Assessing business participation in government and industry sponsored voluntary environmental programs, Journal of Public Administration Research and Theory, March 2010.

Dasgupta, Susmita, Hemamala Hettige, David Wheeler. What Improves Environmental Compliance? Evidence from Mexican Industry, Volume 39, Issue 1, January 2000, Pages 39-66

Frey, Bruno S., Yuval Feldman. Five Models of Regulatory Compliance Motivation Empirical Findings and Normative Implications, Bar-Ilan University Public Law and Legal Theory, Working Paper No. 12-10, 2010.

Frey, Bruno S., Alois Stutzer. Environmental Morale and Motivation, Institute for Empirical Research in Economics University of Zurich, Working Paper No. 288, April 2006

Gamper-Rabindran, Shanti, Stephen R Finger. Does industry self-regulation reduce pollution? Responsible Care in the chemical industry, J Regul Econ, 43:1-30, 2013.

Gunningham, Neil., Robert A Kagan., Dorothy Thornton. Social License and Environment Protection: Why Businesses Go Beyond Compliance, 29 Law \& Soc. Inquiry 307, 2004. 
Gunningham, Neil, Darren Sinclair. Regulatory Pluralism: Designing Policy Mixes for Environmental Protection, Law and Policy, Vol. 21, No. 1, 49-76, 1999.

Higley, Charles J, François Lévêque. Environmental Voluntary Approaches: Research Insights for Policy-Makers, (CERNA, Centre d'économie industrielle Ecole Nationale Supérieure des Mines de Paris), 2001.

ICEL, Catatan Awal Tahun 2019: "Narasi Yang Hilang Dalam Proyeksi Kebijakan Lingkungan Hidup Capres-Cawapres", ICEL, 2019

Ispo, http://www.ispo-org.or.id/index. php?option=com_content\&view $=$ art icle\&id=114\&Itemid=279\&lang=ina, diakses tanggal 22 Agustus 2019

Kementerian Perindustrian, http:// www.kemenperin.go.id/jawaban attachment.php?id=6000\&id $\mathrm{t}=21781$, diakses tanggal 20 januari 2019

Lee, Eungkyoon. Information Disclosure and Environmental Regulation: Green lights and Gray Areas, Regulation And Governance, v.4 n. 3, p. 303-328, 2010

Lopez, Jorge Garcia. The Institutional History Of Indonesia's Environmental Rating And Public Disclosure Program - Proper, 2011, http://erblegacy.snre. umich.edu/News-and-Events / news-events-docs/11-12/ecolabels2011/JorgeGarciaLopez.pdf, diakses tanggal 14 Juli 2018

Pemerintah Provinsi Lampung, 12 Juni 2016, http://lampungprov.go.id/ berita/gubernur-beri-penghargaankepada-pemkabpemkot-danperusahaan-peduli-lingkungan. html, diakses tanggal 31 Juli 2018

Potoski, Matthew, Aseem Prakash. Covenants with Weak Swords: ISO 14001 and Facilities' Environmental Performance, Journal of Policy Analysis and Management, Vol. 24, No. 4, pp. 745-769, Fall, 2005

Prakash, Aseem, Matthew Potoski. Voluntary Environmental Programs: A Comparative Perspective, Journal of Policy Analysis and Management, Vol. 31, No. 1, pp. 123-138, WINTER, 2012

Scholz, John T., "Cooperative regulatory enforcement and the politics of administrative effectiveness", American Political Science Review, 85 (1), 11536., 1991

Stretesky, Paul B. Corporate Self-Policing And The Environment, Criminology Volume 44 Number 3, 2006.

Telle, Kjetil. The threat of regulatory environmental inspection: impact on plant performance, J Regul Econ, 35:154-178, 2009 
Tietenberg, Tom. Disclosure Strategies for Pollution Control, Environmental and Resource Economics, 11(3-4): 587602, 1998.

Wamad, Sudirman. "34 Rumah Sakit Diduga Buang Limbah Medis di Cirebon", Kamis 14 Desember 2017, sumber https://news.detik.com/ berita-jawa-barat/d-3770128/34rumah-sakit-diduga-buang-limbahmedis-di-cirebon, diakses tanggal 1 Agustus 2018.

Wibisana, Andri G. Instrumen Ekonomi, Command And Control dan Instrumen Lainnya: Kawan Atau Lawan?, Suatu Tinjauan Berdasarkan Smart Regulation, Bina Hukum Lingkungan, Volume 4, Nomor 1, Oktober 2019

\section{Lain-lain}

Badan Pusat Statistik, https://www.bps. go.id/statictable/2010/01/18/1053/ jumlah-industri-pengolahan-besardan-sedang-jawa-dan-1uarjawa-2001-2015.html, diakses 22 Januari 2018.

USAID, ICEL, MOE, AECEN, 2008, Environmental Compliance and Enforcement in Indonesia Rapid Assessment, sumber : https://www. aecen.org/sites/default/files/ID_ Assessment.pdf, diakses 14 Juli 2018

Wibisana, Andri G., Penaatan Hukum Lingkungan: Command and Control, Instrumen Ekonomi, dan Penaatan Sukarela, Bahan Ajar Fakultas Hukum UI, 2016. 